\title{
Selective Overexpression of Collybistin in Mouse Hippocampal Pyramidal Cells Enhances GABAergic Neurotransmission and Protects against PTZ- Induced Seizures
}

\author{
Shanu George, Shaun James, and Angel L. De Blas
}

https://doi.org/10.1523/ENEURO.0561-20.2021

Department of Physiology and Neurobiology, University of Connecticut, Storrs, CT 06269

\begin{abstract}
Collybistin $(\mathrm{CB})$ is a rho guanine exchange factor found at GABAergic and glycinergic postsynapses that interacts with the inhibitory scaffold protein, gephyrin, and induces accumulation of gephyrin and GABA type-A receptors $\left(G A B A_{A} R s\right)$ to the postsynapse. We have previously reported that the isoform without the src homology $3(\mathrm{SH} 3)$ domain, CBSH3-, is particularly active in enhancing the GABAergic postsynapse in both cultured hippocampal neurons as well as in cortical pyramidal neurons after chronic in vivo expression in in utero electroporated (IUE) rats. Deficiency of $\mathrm{CB}$ in knock-out (KO) mice results in absence of gephyrin and gephyrin-dependent $\mathrm{GABA}_{A} R s$ at postsynaptic sites in several brain regions, including hippocampus. In the present study, we have generated an adeno-associated virus (AAV) that expresses CBSH3- in a cre-dependent manner. Using male and female VGLUT1-IRES-cre or VGAT-IRES-cre mice, we explore the effect of overexpression of $\mathrm{CBSH} 3-$ in hippocampal pyramidal cells or hippocampal interneurons. The results show that: (1) the accumulation of gephyrin and $\mathrm{GABA}_{\mathrm{A}} \mathrm{Rs}$ at inhibitory postsynapses in hippocampal pyramidal neurons or interneurons can be enhanced by CBSH3- overexpression; (2) overexpression of CBSH3- in hippocampal pyramidal cells can enhance the strength of inhibitory neurotransmission; and (3) these enhanced inhibitory synapses provide protection against pentylenetetrazole (PTZ)-induced seizures. The results indicate that this AAV vector carrying CBSH3- can be used for in vivo enhancement of GABAergic synaptic transmission in selected target neurons in the brain.
\end{abstract}

Key words: AAV; collybistin; GABA; gephyrin; PTZ

\section{Significance Statement}

Excessive or imbalanced excitation in the hippocampus can result in acute or chronic pathologic conditions, such as seizures, epilepsy, and learning impairments. It is therefore important to uncover target genes that can be manipulated to restore or prevent this imbalance. This study uses a novel adeno-associated virus (AAV) to express collybistin (CB)SH3- in select cells of the hippocampus. We have found that overexpression of this protein enhances GABAergic inhibitory synaptic transmission. The results also bring attention to $\mathrm{CB}$ as a possible target for therapeutic intervention aimed to restore the balance between excitation and inhibition.

Received December 27, 2020; accepted May 23, 2021; First published June 3, 2021.

The authors declare no competing financial interests.
Author contributions: S.G. and A.L.D. designed research; S.G. and S.J. performed research; S.G. and S.J. analyzed data; S.G., S.J., and A.L.D. wrote the paper. 


\section{Introduction}

Phasic inhibitory neurotransmission in the central nervous system is accomplished through the action of the neurotransmitters GABA or glycine acting on ligand-gated channels which primarily cluster at postsynaptic sites. GABA type-A receptors $\left(\mathrm{GABA}_{\mathrm{A}} \mathrm{Rs}\right)$ concentrate at postsynaptic sites through interactions with postsynaptic proteins, including anchoring on the inhibitory scaffolding protein, gephyrin (Kneussel et al., 1999; Tretter et al., 2008, 2011; Saiepour et al., 2010; Mukherjee et al., 2011). Collybistin (CB) is a guanine exchange factor that interacts with gephyrin, inducing the recruitment of gephyrin and $\mathrm{CB}$, itself, to GABAergic postsynapses (Kins et al., 2000; Grosskreutz et al., 2001; Reddy-Alla et al., 2010). Rodents express several isoforms of $\mathrm{CB}$ that differ in $\mathrm{C}$ termini (CB1, CB2, CB3), but can also either possess or lack a regulatory src homology $3(\mathrm{SH})$ domain (Kins et al., 2000; Harvey et al., 2004). Isoforms that possess the $\mathrm{SH} 3$ domain $(\mathrm{CBSH}+)$ are in an auto-inhibited conformation, thus preventing the pleckstrin homology $(\mathrm{PH})$ domain of $\mathrm{CBSH} 3+$ from binding to phosphoinositides of the neuronal membrane (Soykan et al., 2014; Papadopoulos et al., 2015; Ludolphs et al., 2016) unless auto-inhibition is removed through the binding of neuroligin-2 (NL2) or $\mathrm{GABA}_{\mathrm{A}} \mathrm{R}$ subunit- $\alpha 2$ to the $\mathrm{SH} 3$ domain, or the small GTPase, TC10, to the PH domain (Poulopoulos et al., 2009; Saiepour et al., 2010; Mayer et al., 2013; Papadopoulos et al., 2017; Nathanson et al., 2019). Isoforms that lack the SH3 domain (CBSH3-), are not constrained in this fashion, inducing the formation of submembranous gephyrin clusters, as demonstrated in HEK and COS-7 cells (Kins et al., 2000; Harvey et al., 2004; Poulopoulos et al., 2009).

Studies of $\mathrm{CB}$ knock-out (KO) mice reveal that loss of $C B$ results in severe disruption to clustering of gephyrin and $\mathrm{GABA}_{A} \mathrm{Rs}$ in certain brain regions, including the hippocampus (Papadopoulos et al., 2007, 2008). This results in decreases in GABAergic neurotransmission, deficiencies in synaptic plasticity, increased levels of anxiety, and impaired spatial learning in CB KO mice. In humans, a mutation in ARHGEF9, the gene that encodes CB, was first identified in a patient with epileptic encephalopathy (Harvey et al., 2004) but additional pathogenic mutations have since been identified in patients, contributing to a spectrum of ailments that include epilepsy, hyperekplexia, intellectual disability, anxiety, autism, and schizophrenia (Marco et al., 2008; Kalscheuer et al., 2009; Lesca et al.,

This work was supported by the National Institutes of Health National Institute of Neurological Disorders and Stroke Grant R01NS038752 (to A.L.D.) and by a University of Connecticut Research Incentive Program grant (A.L.D.).

Acknowledgements: We thank Prof. K. Harvey (UCL School of Pharmacy, London, UK) and Prof. R. J. Harvey (University of the Sunshine Coast, Sippy Downs, Australia) for providing the Myc-CB plasmid.

Correspondence should be addressed to Angel L. De Blas at angel. deblas@uconn.edu.

https://doi.org/10.1523/ENEURO.0561-20.2021

Copyright $@ 2021$ George et al.

This is an open-access article distributed under the terms of the Creative Commons Attribution 4.0 International license, which permits unrestricted use, distribution and reproduction in any medium provided that the original work is properly attributed.
2011; Shimojima et al., 2011; Lionel et al., 2013; Long et al., 2015; Bhat et al., 2016; Klein et al., 2017; Wang et al., 2018; Aarabi et al., 2019; Chiou et al., 2019; Yao et al., 2020).

Overexpression of gephyrin or $\mathrm{GABA}_{A} \mathrm{Rs}$ does not significantly affect synaptic $G_{A B A} R$ or gephyrin clustering in cultured hippocampal neurons (Chiou et al., 2011). However, it has been demonstrated that overexpression of CBSH3- in cultured hippocampal neurons induces the formation of large synaptic gephyrin and $\mathrm{GABA}_{A} R$ clusters (Kalscheuer et al., 2009; Chiou et al., 2011; Tyagarajan et al., 2011; Soykan et al., 2014). In the present study, we examined the effect of overexpressing a constitutively active isoform of $\mathrm{CB}, \mathrm{CB} 2 \mathrm{SH} 3-$, in selected cells of the dorsal hippocampus in adult mice. By overexpressing CB2SH3- in specific neuron-types, and in adulthood, we aimed to address whether the increase in CB2SH3- expression enhances the postsynaptic accumulation of gephyrin and $\mathrm{GABA}_{A} \mathrm{Rs}$, GABAergic synaptic transmission in the developed hippocampus, and whether it can effectively protect against pentylenetetrazole (PTZ)induced acute seizures.

\section{Materials and Methods}

\section{Animals}

All animals included in this study were treated following protocols approved by the Institutional Animal Care and Use Committee (IACUC) at the University of Connecticut and follow National Institute of Health guidelines. Both male and female mice of VGAT-IRESCre (JAX: Slc32a1tm2(cre)Lowl/J; stock \#016962) or VGLUT1-IRES2-Cre (JAX: B6;129S-Slc17a7tm1.1(cre) $\mathrm{Hze/J;} \mathrm{stock} \mathrm{\# 023527)} \mathrm{background} \mathrm{were} \mathrm{used.}$

\section{Materials}

For immunofluorescence studies, mouse mAb gephyrin (1:200; RRID: https://scicrunch.org/resolver/AB_ 887717), guinea pig anti-VGAT (1:1000; RRID: AB_ 887873), and rabbit anti-CB (1:1000; RRID: AB_2619977), were from Synaptic Systems. The rabbit anti-CB antibody detects both $\mathrm{CBSH} 3-$ and $\mathrm{CBSH} 3+$ isoforms (Soykan et al., 2014; George et al., 2021). Mouse anti-HA (1:1000; RRID: AB_10063630) was from Covance. The rabbit antibody against $\mathrm{GABA}_{A} \mathrm{R}$-subunit $\gamma 2$ (1:25; RRID: $\mathrm{AB}$ 2314477; to amino acids 1-15: QKSDDDYEDYASNKT) was raised and affinity-purified (on immobilized antigen peptide) in our laboratory. In cultured hippocampal neurons and in brain tissue, this antibody shows clustered labeling that colocalizes highly with that of antibodies to other $\mathrm{GABA}_{A} R$ subunits and to gephyrin. It also shows apposition to glutamate decarboxylase (GAD)-containing terminals. It has been described and characterized elsewhere (Khan et al., 1994; Christie and De Blas, 2003; Charych et al., 2004a,b; Li et al., 2005b, 2007, 2010, 2012; Serwanski et al., 2006; Yu et al., 2007, 2008; Chiou et al., 2011; Jin et al., 2014; Fekete et al., 2015, 2017). Species-specific anti-IgG secondary antibodies were raised in goat and labeled with Alexa Fluor 568 or 647 (Invitrogen). PTZ (catalog \#18682) used for behavioral studies was from Cayman Chemicals. For 
electrophysiological studies, tetrodotoxin (TTX; catalog \#T550) was from Alomone Labs; CNQX (catalog \#C127) and picrotoxin (catalog \#P1675) were from Sigma.

\section{Construction and production of AAV9/hSyn-DIO-HA- CB2SH3()-IRES-mCitrine}

The cDNA for the constitutively active isoform of $\mathrm{CB}$ tagged with $\mathrm{HA}$ (HA-CB2SH3-) was cloned into the pAAV2hSyn-dF-HA-KORD-IRES-mCitrine plasmid (gift from Bryan Roth; Addgene plasmid \# 65417; http://n2t.net/ addgene:65417; RRID: https://scicrunch.org/resolver/ Addgene_65417) to replace HA-KORD. The pAAV2-hSynDIO-HA-CB2SH3(-)-IRES-mCitrine was sent to the UNC Vector Core for AAV9 production (Zhu et al., 2014). This plasmid has been submitted to Addgene (https://www. addgene.org/160069/).

\section{Viral infusion in vivo}

Adult mice (five to eight weeks old) were anesthetized with isoflurane and placed into a stereotactic frame to prevent any head movement. The viral constructs, AAV/9hSyn-DIO-HA-CB2SH3(-)-IRES-mCitrine (HACB2-AAV) or AAV/5-hSyn-DIO-EGFP (EGFP-AAV; UNC Vector Core; Roth Lab) were injected into the dorsal hippocampus (from bregma: anterior-posterior: -2.0 , medial-lateral: \pm 1.6, dorsal-ventral: -1.6$)$ using a $1-\mu \mathrm{l}$ Hamilton syringe at a rate of $20 \mathrm{nl} / \mathrm{min}$, followed by $5 \mathrm{~min}$ before retraction of the syringe. Volumes used were $250 \mathrm{nl}$ unilaterally for immunohistochemical studies and $500 \mathrm{nl}$ bilaterally for electrophysiological and behavioral studies (titers: $7.2 \times 10^{12}$ $\mathrm{vg} / \mathrm{ml}$ EGFP-AAV; $7.1 \times 10^{12} \mathrm{vg} / \mathrm{ml}$ HACB2-AAV). After surgery, mice were returned to their cages for two to four weeks of recovery before use for behavioral, electrophysiology, or immunohistochemical study.

\section{Tissue preparation, immunohistology, and image acquisition}

Three weeks after unilateral viral injection, mice were deeply anesthetized with an overdose of ketamine/xylazine $(60 / 8 \mathrm{mg} / \mathrm{kg}$ ) and cardiac perfusion was performed with $0.12 \mathrm{~m}$ phosphate buffer (PB; pH 7.4) followed by $4 \%$ PLP fixative in $0.12 \mathrm{~m}$ PB (4\% paraformaldehyde, $1.37 \%$ lysine, and $0.21 \%$ sodium periodate). Brains were cryoprotected with $30 \%$ sucrose, frozen, and sectioned with a freezing microtome $(25 \mu \mathrm{m}$ thick) and stored in $0.02 \%$ sodium azide in $0.1 \mathrm{M} \mathrm{PB}, \mathrm{pH} 7.4$ at $4^{\circ} \mathrm{C}$. Immunofluorescence was performed as described elsewhere (Li et al., 2005a; Fekete et al., 2017; Miralles et al., 2020). Briefly, free-floating brain sections were incubated with $5 \%$ normal goat serum, $0.3 \%$ Triton $\mathrm{X}-100$ in $0.1 \mathrm{~m}$ PB for $1 \mathrm{~h}$ at room temperature. Sections were then incubated for $2 \mathrm{~d}$ in primary antibody cocktails raised in different species in 2\% NGS/0.3\% Triton $\mathrm{X}-100$ in $0.1 \mathrm{M} \mathrm{PB}$ at $4^{\circ} \mathrm{C}$. Sections were washed and incubated in a mixture of fluorophore-conjugated secondary antibodies in 2\% NGS/0.3\% Triton X-100 in $0.1 \mathrm{M} \mathrm{PB}$ for $1 \mathrm{~h}$ at room temperature. When necessary, a DAPI counterstain (200 nм) was applied following a wash after secondary incubation. Sections were then washed again and mounted onto gelatin-coated glass slides with Prolong Gold Antifade mounting solution (Invitrogen). Confocal images of brain sections were acquired using an A1R laser scanning confocal microscope (Nikon Instruments) with a Plan Apo VC $60 \times / 1.4$ oil immersion objective. For the quantifications presented in Figure 1. The images were collected with a LSM 800 confocal laser-scanning microscope (Zeiss) with a $63 \times 1$ 1.4 oil-immersion objective. The pinhole was set at 1.2 Airy units. Images were collected as single optical sections. The low-magnification images of brain sections for EGFP/ mCitrine/DAPI were collected by epifluorescence with a Plan Fluor $10 \times / 0.3$ objective.

\section{Electrophysiological recordings}

Mice were anesthetized by administration of ketamine $(375 \mathrm{mg} / \mathrm{kg}$, i.p.) and xylazine $(25 \mathrm{mg} / \mathrm{kg}$, i.p.) and rapidly decapitated; cortex was removed, and slices $(250 \mu \mathrm{m})$ were cut using a microslicer (DSK 1500E; Dosaka) in icecold substituted Ringer solution containing the following: $83 \mathrm{~mm} \mathrm{NaCl}, 26 \mathrm{~mm} \mathrm{NaHCO} 3,1.25 \mathrm{~mm} \mathrm{NaH}_{2} \mathrm{PO}_{4}, 2.5 \mathrm{~mm}$ $\mathrm{KCl}, 22 \mathrm{~mm}$ dextrose, $72 \mathrm{~mm}$ sucrose, $0.5 \mathrm{~mm} \mathrm{MgCl} 2,3.3$ $\mathrm{mm} \mathrm{CaCl}_{2}, 1.3 \mathrm{~mm} \mathrm{Na-ascorbate,} \mathrm{and} 0.6 \mathrm{~mm} \mathrm{Na-pyru-}$ vate. Slices were incubated for $30 \mathrm{~min}$ at $37^{\circ} \mathrm{C}$ and kept at room temperature in a normal Ringer's solution containing: $140 \mathrm{~mm} \mathrm{NaCl}, 3 \mathrm{~mm} \mathrm{KCl}, 2 \mathrm{~mm} \mathrm{MgCl}$, $2 \mathrm{~mm} \mathrm{CaCl}_{2}$, $10 \mathrm{~mm}$ HEPES, and $10 \mathrm{~mm}$ glucose. Both substituted and normal Ringer's solutions were bubbled with $95 \% \mathrm{O}_{2}$ and $5 \% \mathrm{CO}_{2}(\mathrm{pH} 7.3)$.

Individual slices containing the CA1 hippocampus were transferred to a recording chamber mounted on a fixed-stage microscope (Olympus BX5.1WI) and perfused continuously ( $\sim 2 \mathrm{ml} / \mathrm{min}$ ) with normal Ringer's solution (equilibrated with $5 \% \mathrm{CO}_{2} ; \mathrm{pH} 7.3$ ). Transfected CA1 hippocampal neurons were visually identified by fluorescent signal from EGFP or mCitrine. All recordings were made with an Axopatch $200 \mathrm{~B}$ patchclamp amplifier, digitized with a Digidata 1322A A/D converter, and recorded using PCLAMP 10.0 software (Molecular Devices). Recordings were obtained at room temperature $\left(\sim 22^{\circ} \mathrm{C}\right)$ with patch electrodes pulled from borosilicate glass capillaries (Harvard Apparatus) on a twostage puller (P-97; Sutter Instrument) to a DC resistance of 5-7 $M \Omega$ when filled with a pipette solution containing the following: $130 \mathrm{~mm} \mathrm{CsCl}, 8.5 \mathrm{~mm} \mathrm{NaCl}, 5 \mathrm{~mm}$ HEPES, $4 \mathrm{~mm} \mathrm{MgCl}_{2}$, $4 \mathrm{~mm}$ Mg2-ATP, $0.3 \mathrm{~mm} \mathrm{Na}$-GTP, and 0.6 mM EGTA. Electrode tips were coated with Sylgard 184 (Dow Corning). A gigaohm seal $(\geq 1 \mathrm{G} \Omega$ ) was achieved using a cell-attached voltage-clamp configuration with holding potential matched to the resting membrane potential $\left(\mathrm{V}_{\text {hold }}=-70 \mathrm{mV}\right)$ and with no current generated by the amplifier $\left(\mathrm{l}_{\mathrm{amp}}=0 \mathrm{pA}\right)$. Whole-cell access $(\leq 20 \mathrm{M} \Omega)$ was obtained to characterize spontaneous synaptic input. Spontaneous mIPSCs were characterized in the presence of bath applied CNQX $(10 \mu \mathrm{M})$ and TTX $(0.5 \mu \mathrm{M})$, and events were confirmed with bath application of picrotoxin $(100 \mu \mathrm{M})$. mIPSCs were analyzed using Clampfit 10.7 and detected with characteristic kinetics (fast rising phase followed by a slow decay). Each automatically detected event was also visually inspected to exclude false positives. Recordings were discarded if Ra varied $10 \%$ 

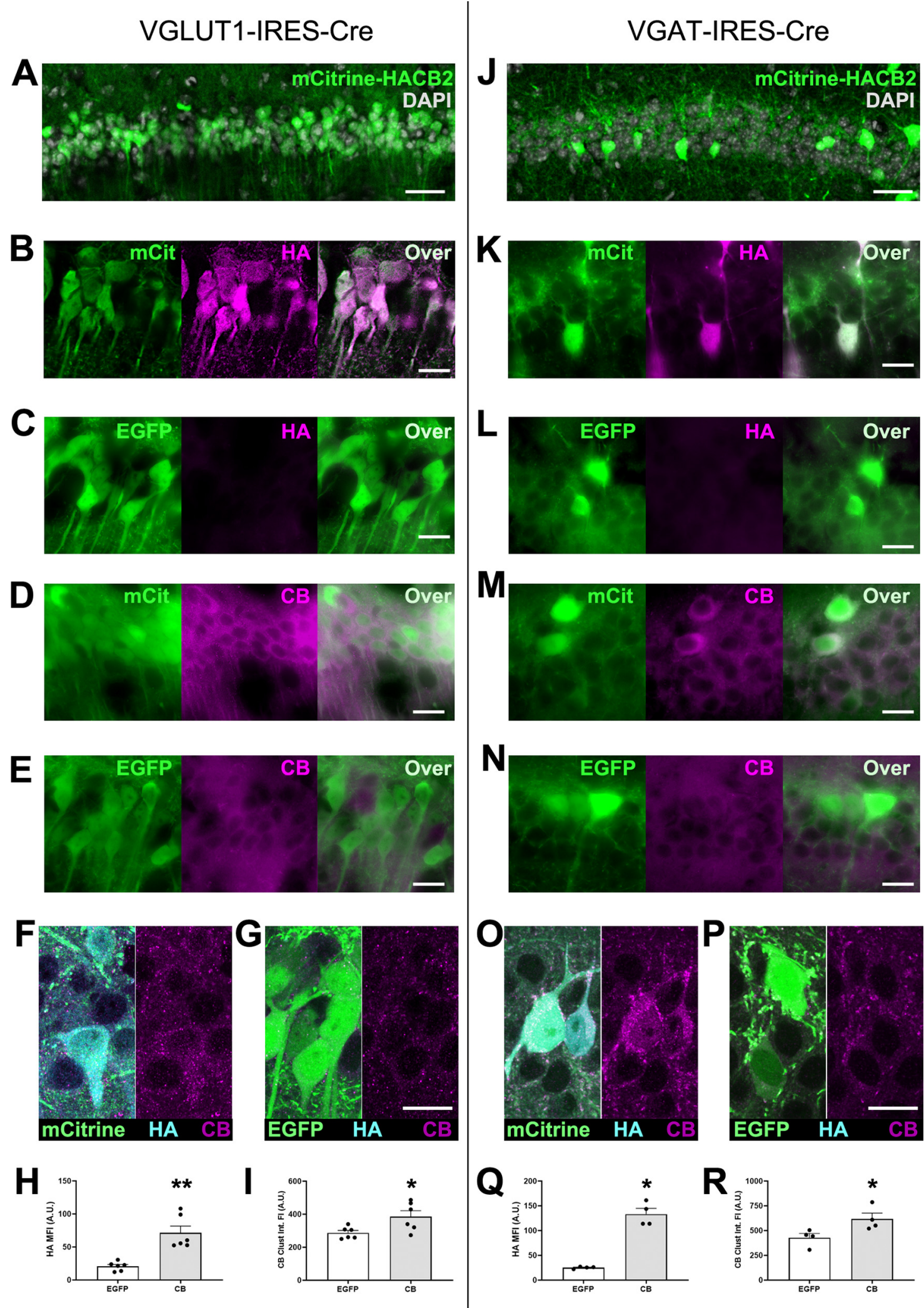

Figure 1. Injection of hippocampal CA1 with AAV-DIO-HA-CB2SH3(-)-IRES-mCitrine results in overexpression of $m$ Citrine and HA-CB2SH3 (-) in a cre-dependent manner. $\boldsymbol{A}-\boldsymbol{I}$, The mCitrine-HACB2-AAV $(\boldsymbol{A}, \boldsymbol{B}, \boldsymbol{D}, \boldsymbol{F})$ or a control EGFP-AAV $(\boldsymbol{C}, \boldsymbol{E}, \boldsymbol{G})$ were injected into CA1 of VGLUT1-IRES-cre mice, resulting in expression of mCitrine or EGFP in the glutamatergic pyramidal cell, and images were taken with epifluorescence microscopy $(\boldsymbol{A}-\boldsymbol{E})$ or confocal microscopy $(\boldsymbol{F}, \boldsymbol{G})$. In mCitrine-HACB2-AAV-injected mice, the transduced pyramidal cells expressing 
continued

mCitrine also overexpressed HA-CB2SH3-, as detected by Ms anti-HA (B, $\boldsymbol{F})$ and Rb anti-CB $(\boldsymbol{D}, \boldsymbol{F})$. In CA1 of EGFP-AAV-injected mice, HA was not detected $(\boldsymbol{C}, \boldsymbol{G})$, and only a low endogenous level of $\mathrm{CB}(\boldsymbol{E}, \boldsymbol{G})$ was visible. Quantification from confocal images for mean intensity of HA immunofluorescence in SP is presented in $\boldsymbol{H}$, and integrated intensity of CB immunofluorescent clusters is presented in $\boldsymbol{I}$. $\boldsymbol{J} \boldsymbol{R}$, The mcitrine-HACB2-AAV $(\boldsymbol{J}, \boldsymbol{K}, \boldsymbol{M}, \mathbf{O})$ or a control EGFP-AAV $(\boldsymbol{L}, \boldsymbol{N}, \boldsymbol{P})$ were injected into CA1 of VGAT-IRES-cre mice, resulting in overexpression of mCitrine or EGFP in GABAergic interneurons and images were taken with epifluorescence microscopy $(\boldsymbol{J}-\mathbf{N})$ or confocal microscopy $(\mathbf{O}-\boldsymbol{P})$. In mCitrine-HACB2-AAV-injected mice, the transduced interneurons expressed mCitrine and overexpressed HA-CB2SH3-, as detected by Ms anti-HA $(\boldsymbol{K}, \mathbf{O})$ and Rb anti-CB $(\boldsymbol{M}, \mathbf{O})$. In CA1 of EGFP-AAV-injected mice, HA was not detected $(\boldsymbol{L}, \boldsymbol{P})$, and only a low endogenous level of CB $(\boldsymbol{N}, \boldsymbol{P})$ was visible. Quantification from confocal images for mean intensity of HA immunofluorescence in interneurons is presented in $\boldsymbol{Q}$, and integrated intensity of perisomatic CB immunofluorescent clusters is presented in $\boldsymbol{R}$. Scale bars: $25 \mu \mathrm{m}(\boldsymbol{A}, \boldsymbol{J})$ and $10 \mu \mathrm{m}(\boldsymbol{B}-\mathbf{G}, \boldsymbol{K}-\boldsymbol{P})$. Asterisks in the quantification graphs indicate significance using Mann-Whitney $U$ test, ${ }^{*} p<0.05,{ }^{* *} p<0.01$.

during an experiment, and capacitance and Ra compensation $(70 \%)$ were used to minimize voltage errors.

\section{Behavioral study}

Preliminary trials were performed on naive mice to determine dose of PTZ that would reliably induce acute seizures while minimizing mortality. Three weeks after bilateral viral infusion, mice were subjected to behavioral study. Mice were given a single injection of PTZ $(40 \mathrm{mg} /$ $\mathrm{kg}$, i.p.) to induce acute seizures. The mice were then placed into a cage and behavior was observed. Seizures were scored according to a modified Racine scale (Racine, 1972; Lüttjohann et al., 2009; Singh et al., 2016) with the following scores: 1, sudden behavioral arrest; 2 , facial jerking; 3 , myoclonic jerks; 4, clonic seizure, sitting; 5 , clonic, tonic-clonic seizure, lying on belly; 6 , clonic, tonic-clonic seizure with loss of posture and wild jumping; with notation of time of onset of each intensity of seizure and tallying of maximal seizure intensity in 2-min bins. Seizure behavior typically subsides by 30 min after PTZ administration, so animals were then returned to their home cages. Animals were killed, brains collected, and sections examined by epifluorescence microscopy to confirm appropriate transduction of hippocampal CA1.

\section{Experimental design and statistical analysis}

All image analysis was performed using ImageJ (RRID: SCR_003070). For analysis of immunofluorescence, brain sections were analyzed from mice injected with HACB2AAV (VGLUT1-cre: $n=6$, VGAT-cre: $n=4$ ) or EGFP-AAV (VGLUT1-cre: $n=6$, VGAT-cre: $n=4$ ). For each animal, each quantified value is the average of 10-15 measurements [regions of interest (ROIs) or individual interneurons], as explained below. Because of the densely packed nature of transduced CA1 pyramidal cells in VGLUT1-cre mice, ROls were used to measure impact of viral transduction. In each section, five images were taken per hemisphere, and three ROls with areas of $500 \mu \mathrm{m}^{2}$ were created within stratum pyramidale (SP) of CA1 in each to determine changes in perisomatic synapses. These values were averaged to present a single value for each animal. This was repeated within stratum radiatum (SR) and stratum oriens (SO) to measure changes in dendritic synapses. To determine changes in synaptic proteins in transduced interneurons of CA1 (of VGAT-cre mice), cell bodies within SP were outlined and then expanded inward/outward to create a 15-pixel thick ring-shaped $\mathrm{ROI}$ around transduced neurons. VGAT, gephyrin, and
$\mathrm{GABA}_{\mathrm{A}} \mathrm{R}-\gamma 2$-subunit immunoreactivities were then measured in these ROls. Five to seven cells were measured per brain section, two sections per animal, to calculate an average value for each animal. Since only one hemisphere was injected, the other hemisphere served as an internal control to ensure there was no significant variability from mouse to mouse. Additional injected mice were excluded from study in cases of off-target injection or lack of transduction (VGAT-cre: four mice, VGLUT1-cre: three mice). For electrophysiological and behavioral study in VGLUT1cre mice, mice were injected bilaterally. For electrophysiological experiments, data are presented from transduced cells (HACB2-AAV: $n=5$, EGFP-AAV: $n=6 ; 1$ cell per mouse) from injected mice. The final 100 events before bath application of picrotoxin was used for analysis. For behavioral experiments, data are presented for injected mice (HACB2-AAV: $n=15$, EGFP-AAV: $n=12$ ), and the observer was blinded to the condition of the mouse during seizure scoring. Additional injected mice were excluded from study if they died after PTZ administration (HACB2AAV: one mouse, EGFP-AAV: two mice) or if brain examination determined off-target injection or lack of transduction. No additional mortality was observed during or following procedures in adeno-associated virus (AAV)-injected mice. Statistical analyses were performed using Prism 8 (GraphPad). Statistical tests include MannWhitney $U$ tests for two-group comparisons when sample size was below 10, and unpaired $t$ tests when sample size was $>10$, Kolmogorov-Smirnov tests, and Fisher's exact test. Statistical data can be found in Table 1. Summary data are presented as mean \pm SEM from $n$ mice or neurons, as indicated.

\section{Results}

\section{Mice injected with AAV-HA-CB2SH3- express both mCitrine and $\mathrm{HA}-\mathrm{CB}$}

In order to validate that our cre-dependent viral construct was capable of transduction of appropriate cells in $\mathrm{CA} 1$, we examined the pattern of $\mathrm{mCitrine}$ and $\mathrm{HA}$ expression in injected mice.

In VGLUT1-IRES-cre mice injected with the HACB2AAV, large swathes of the pyramidal cell layer in CA1 expressed mCitrine (Fig. 1A), interspersed with the occasional non-transduced cell, likely indicating an interneuron. As expected, none of the cells in SO were transduced, since cell bodies there belong to GABAergic cells. The transduced cells showing mCitrine fluorescence also 
Table 1: Descriptive and summary statistics by figure

\begin{tabular}{|c|c|c|c|c|}
\hline Data & Figure & Statistical test & Test values & $p$ value \\
\hline \multicolumn{5}{|c|}{$\begin{array}{l}\text { Immunofluorescence data: } \\
\text { VGLUT1-cre: }\end{array}$} \\
\hline HA MFI & 1 & Mann-Whitney $U$ test & $\begin{array}{l}\text { Median EGFP: } 22.09 \\
\text { Median CB: } 57.90 \\
N=6, U=0\end{array}$ & 0.0022 \\
\hline CB integrated FI & 1 & Mann-Whitney $U$ test & $\begin{array}{l}\text { Median EGFP: } 283.3 \\
\text { Median CB: } 384.7 \\
N=6, U=5\end{array}$ & 0.0411 \\
\hline SO Geph size & 2 & Mann-Whitney $U$ test & $\begin{array}{l}\text { Median EGFP: } 0.2559 \\
\text { Median CB: } 0.3428 \\
N=6, U=0\end{array}$ & 0.0022 \\
\hline SP Geph size & 2 & Mann-Whitney $U$ test & $\begin{array}{l}\text { Median EGFP: } 0.1923 \\
\text { Median CB: } 0.2491 \\
N=6, U=2\end{array}$ & 0.0087 \\
\hline SR Geph size & 2 & Mann-Whitney $U$ test & $\begin{array}{l}\text { Median EGFP: } 0.2360 \\
\text { Median CB: } 0.2838 \\
N=6, U=4\end{array}$ & 0.0260 \\
\hline SO Geph density & 2 & Mann-Whitney $U$ test & $\begin{array}{l}\text { Median EGFP: } 0.1133 \\
\text { Median CB: } 0.1691 \\
N=6, U=1\end{array}$ & 0.0043 \\
\hline SP Geph density & 2 & Mann-Whitney $U$ test & $\begin{array}{l}\text { Median EGFP: } 0.0723 \\
\text { Median CB: } 0.1331 \\
N=6, U=3\end{array}$ & 0.0152 \\
\hline SR Geph density & 2 & Mann-Whitney $U$ test & $\begin{array}{l}\text { Median EGFP: } 0.1136 \\
\text { Median CB: } 0.1922 \\
N=6, U=3\end{array}$ & 0.0152 \\
\hline SO $\gamma 2$ size & 2 & Mann-Whitney $U$ test & $\begin{array}{l}\text { Median EGFP: } 0.1760 \\
\text { Median CB: } 0.1715 \\
N=6, U=11\end{array}$ & 0.8413 \\
\hline SP $\gamma 2$ size & 2 & Mann-Whitney $U$ test & $\begin{array}{l}\text { Median EGFP: } 0.1647 \\
\text { Median CB: } 0.2013 \\
N=6, U=2\end{array}$ & 0.0317 \\
\hline SR $\gamma 2$ size & 2 & Mann-Whitney $U$ test & $\begin{array}{l}\text { Median EGFP: } 0.1522 \\
\text { Median CB: } 0.1562 \\
N=6, U=10\end{array}$ & 0.6905 \\
\hline SO $\gamma 2$ density & 2 & Mann-Whitney $U$ test & $\begin{array}{l}\text { Median EGFP: } 0.0879 \\
\text { Median CB: } 0.0975 \\
N=6, U=12\end{array}$ & $>0.9999$ \\
\hline SP $\gamma 2$ density & 2 & Mann-Whitney $U$ test & $\begin{array}{l}\text { Median EGFP: } 0.0865 \\
\text { Median CB: } 0.0824 \\
N=6, U=12\end{array}$ & $>0.9999$ \\
\hline SR $\gamma 2$ density & 2 & Mann-Whitney $U$ test & $\begin{array}{l}\text { Median EGFP: } 0.0615 \\
\text { Median CB: } 0.0877 \\
N=6, U=6\end{array}$ & 0.2222 \\
\hline SO VGAT size & 2 & Mann-Whitney $U$ test & $\begin{array}{l}\text { Median EGFP: } 0.2082 \\
\text { Median CB: } 0.2406 \\
N=6, U=9\end{array}$ & 0.1797 \\
\hline SP VGAT size & 2 & Mann-Whitney $U$ test & $\begin{array}{l}\text { Median EGFP: } 0.2447 \\
\text { Median CB: } 0.2910 \\
N=6, U=10\end{array}$ & 0.2403 \\
\hline SR VGAT size & 2 & Mann-Whitney $U$ test & $\begin{array}{l}\text { Median EGFP: } 0.2015 \\
\text { Median CB: } 0.2072 \\
N=6, U=12\end{array}$ & 0.3939 \\
\hline SO VGAT density & 2 & Mann-Whitney $U$ test & $\begin{array}{l}\text { Median EGFP: } 0.0594 \\
\text { Median CB: } 0.0716 \\
N=6, U=10\end{array}$ & 0.2229 \\
\hline SP VGAT density & 2 & Mann-Whitney $U$ test & $\begin{array}{l}\text { Median EGFP: } 0.0705 \\
\text { Median CB: } 0.0799 \\
N=6, U=7\end{array}$ & 0.0931 \\
\hline SR VGAT density & 2 & (Continued) & $\begin{array}{l}\text { Median EGFP: } 0.0778 \\
\text { Median CB: } 0.0787 \\
N=6, U=16\end{array}$ & 0.8182 \\
\hline
\end{tabular}


Table 1: Continued

\begin{tabular}{|c|c|c|c|c|}
\hline Data & Figure & Statistical test & Test values & $p$ value \\
\hline \multicolumn{5}{|l|}{ VGAT-cre } \\
\hline HA MFI & 1 & Mann-Whitney $U$ test & $\begin{array}{l}\text { Median EGFP: } 25.93 \\
\text { Median CB: } 128.9 \\
N=4, U=0\end{array}$ & 0.0286 \\
\hline CB integrated FI & 1 & Mann-Whitney $U$ test & $\begin{array}{l}\text { Median EGFP: } 450.8 \\
\text { Median CB: } 580.9 \\
N=4, U=0\end{array}$ & 0.0286 \\
\hline Geph size & 3 & Mann-Whitney $U$ test & $\begin{array}{l}\text { Median EGFP: } 0.1788 \\
\text { Median CB: } 0.3437 \\
N=4, U=0\end{array}$ & 0.0286 \\
\hline Geph density & 3 & Mann-Whitney $U$ test & $\begin{array}{l}\text { Median EGFP: } 0.2291 \\
\text { Median CB: } 0.4403 \\
N=4, U=0\end{array}$ & 0.0286 \\
\hline$\gamma 2$ size & 3 & Mann-Whitney $U$ test & $\begin{array}{l}\text { Median EGFP: } 0.1706 \\
\text { Median CB: } 0.2151 \\
N=4, U=1\end{array}$ & 0.0571 \\
\hline$\gamma 2$ density & 3 & Mann-Whitney $U$ test & $\begin{array}{l}\text { Median EGFP: } 0.1387 \\
\text { Median CB: } 0.1386 \\
N=4, U=8\end{array}$ & $>0.9999$ \\
\hline VGAT size & 3 & Mann-Whitney $U$ test & $\begin{array}{l}\text { Median EGFP: } 0.3144 \\
\text { Median CB: } 0.3617 \\
N=4, U=4\end{array}$ & 0.3429 \\
\hline VGAT density & 3 & Mann-Whitney $U$ test & $\begin{array}{l}\text { Median EGFP: } 0.2008 \\
\text { Median CB: } 0.2967 \\
N=4, U=5\end{array}$ & 0.4857 \\
\hline \multicolumn{5}{|l|}{ Electrophysiology data } \\
\hline mIPSC amplitude cumulative frequency & 4 & Kolmogorov-Smirnov test & $\begin{array}{l}\text { Kolmogorov-Smirnov } D=0.3283 \\
N=600,500\end{array}$ & $<0.0001$ \\
\hline mIPSC amplitude & 4 & Mann-Whitney $U$ test & $\begin{array}{l}\text { Median EGFP: }-29.84 \\
\text { Median CB: }-41.98 \\
N=6,5, U=4\end{array}$ & 0.0455 \\
\hline mIPSC frequency cumulative frequency & 4 & Kolmogorov-Smirnov test & $\begin{array}{l}\text { Kolmogorov-Smirnov } D=0.1651 \\
N=600,500\end{array}$ & $<0.0001$ \\
\hline mIPSC frequency & 4 & Mann-Whitney $U$ test & $\begin{array}{l}\text { Median EGFP: } 0.2125 \\
\text { Median CB: } 0.4583 \\
N=6,5, U=0\end{array}$ & 0.0043 \\
\hline mIPSC rise time & 4 & Mann-Whitney $U$ test & $\begin{array}{l}\text { Median EGFP: } 0.9404 \\
\text { Median CB: } 1.127 \\
N=6,5, U=0\end{array}$ & 0.0043 \\
\hline mIPSC decay Tau & 4 & Mann-Whitney $U$ test & $\begin{array}{l}\text { Median EGFP: } 15.22 \\
\text { Median CB: } 18.40 \\
N=6,5, U=6\end{array}$ & 0.1255 \\
\hline \multicolumn{5}{|l|}{ Behavioral data } \\
\hline Cumulative seizure score & 5 & Kolmogorov-Smirnov test & $\begin{array}{l}\text { Kolmogorov-Smirnov } D=0.7333 \\
N=12,15\end{array}$ & 0.0006 \\
\hline Latency to seizure score 1 & 5 & Unpaired $t$ test & $\begin{array}{l}\text { Mean EGFP: } 76.42 \\
\text { Mean CB: } 216.1 \\
N=12,14, F=55.84, \mathrm{DFn}=13, \mathrm{Dfd}=11\end{array}$ & 0.0358 \\
\hline Latency to seizure score 2 & 5 & Unpaired $t$ test & $\begin{array}{l}\text { Mean EGFP: } 83.33 \\
\text { Mean CB: } 260.0 \\
N=12,14, F=90.32, \mathrm{DFn}=13, \mathrm{Dfd}=11\end{array}$ & 0.0480 \\
\hline Latency to seizure score 3 & 5 & Unpaired $t$ test & $\begin{array}{l}\text { Mean EGFP: } 108.4 \\
\text { Mean CB: } 252.5 \\
N=12,11, F=45.64, \mathrm{DFn}=10, \mathrm{Dfd}=11\end{array}$ & 0.0912 \\
\hline Latency to seizure score 4 & 5 & Unpaired $t$ test & $\begin{array}{l}\text { Mean EGFP: } 167.6 \\
\text { Mean CB: } 269.9 \\
N=12,9, F=5.961, \mathrm{DFn}=8, \mathrm{Dfd}=11\end{array}$ & 0.1815 \\
\hline Latency to seizure score 5 & 5 & (Continued) & $\begin{array}{l}\text { Mean EGFP: } 210.5 \\
\text { Mean CB: } 381.0 \\
N=10,5, F=10.95, \mathrm{DFn}=4, \mathrm{Dfd}=9\end{array}$ & 0.1062 \\
\hline
\end{tabular}


Table 1: Continued

\begin{tabular}{|c|c|c|c|c|}
\hline Data & Figure & Statistical test & Test values & $p$ value \\
\hline Latency to seizure score 6 & 5 & Unpaired $t$ test & $\begin{array}{l}\text { Mean EGFP: } 239.9 \\
\text { Mean CB: } 298.0 \\
N=9,2, F=\mathrm{n} / \mathrm{a}, \mathrm{DFn}=\mathrm{n} / \mathrm{a}, \mathrm{Dfd}=\mathrm{n} / \mathrm{a}\end{array}$ & 0.5353 \\
\hline Contingency seizure score 1 & 5 & Fisher's exact test & $\begin{array}{l}\text { EGFP: } 12,0 \\
\text { CB: } 14,1 \\
\text { Total: } 26,1 \text { (seized, did not) }\end{array}$ & $>0.9999$ \\
\hline Contingency Seizure score 2 & 5 & Fisher's exact test & $\begin{array}{l}\text { EGFP: } 12,0 \\
\text { CB: } 14,1 \\
\text { Total: } 26,1 \text { (seized, did not) }\end{array}$ & $>0.9999$ \\
\hline Contingency seizure score 3 & 5 & Fisher's exact test & $\begin{array}{l}\text { EGFP: } 12,0 \\
\text { CB: } 11,4 \\
\text { Total: } 23,4 \text { (seized, did not) }\end{array}$ & 0.1060 \\
\hline Contingency seizure score 4 & 5 & Fisher's exact test & $\begin{array}{l}\text { EGFP: } 12,0 \\
\text { CB: } 9,6 \\
\text { Total: } 21,6 \text { (seized, did not) }\end{array}$ & 0.0200 \\
\hline Contingency seizure score 5 & 5 & Fisher's exact test & $\begin{array}{l}\text { EGFP: } 10,5 \\
\text { CB: } 5,10 \\
\text { Total: } 15,12 \text { (seized, did not) }\end{array}$ & 0.0185 \\
\hline Contingency seizure score 6 & 5 & Fisher's exact test & $\begin{array}{l}\text { EGFP: } 9,3 \\
\text { CB: } 2,13 \\
\text { Total: } 11,16 \text { (seized, did not) }\end{array}$ & 0.0020 \\
\hline
\end{tabular}

expressed HA-CB2SH3-, as detected by immunoreactivity with Ms anti-HA (Fig. 1B) and increased immunoreactivity with $\mathrm{Rb}$ anti-CB (Fig. 1D). In CA1 of the VGLUT1IRES-cre mice injected with the EGFP-AAV, we did not detect any $\mathrm{HA}$ (Fig. 1C), nor any increased levels of $\mathrm{CB}$ (Fig. $1 E$ ). To quantify the extent to which $C B$ was expressed over endogenous levels, confocal images were taken (Fig. 1F,G). Mean immunofluorescence intensity (MFI) of HA was significantly increased in HACB2-AAVtransduced neurons (CB: $71.4 \pm 10.3$ A.U.; EGFP: $20.8 \pm 2.8$ A.U.; Mann-Whitney $U$ test, $p=0.002$; Fig. $1 H$ ). Immunofluorescence with the rabbit anti-CB antibody showed that while there was no significant change in the size of CB clusters (Mann-Whitney $U$ test, $p=0.49$ ), there were increases in the density (CB: $0.265 \pm 0.017$ clusters/ $\mu \mathrm{m}^{2}$; EGFP: $0.227 \pm 0.021$ clusters $/ \mu \mathrm{m}^{2}$; Mann-Whitney $U$ test, $p=0.041$ ) and integrated fluorescence intensity of the immunopositive puncta (CB: $386.2 \pm 35.4$ A.U.; EGFP: $287.4 \pm 14.6$ A.U.; Mann-Whitney $U$ test, $p=0.041$; Fig. 1/).

In injected VGAT-IRES-cre mice, mCitrine expression in dorsal hippocampal CA1 matched the expected distribution of interneurons (Fig. 1J), with transduced cells scattered through pyramidal cell layer, as well as cell bodies in the SO. Since our viral construct was inducing bicistronic expression of mCitrine and HA-CB2SH3-, we confirmed that transduced cells were also expressing HA-CB2SH3-. We were able to detect both $\mathrm{HA}$ (Fig. $1 K$ ) and an increased level of $\mathrm{CB}$ (Fig. 1M) in transduced cells of CA1 in mice injected with the HACB2-AAV compared with EGFPAAV-injected mice (Fig. $1 L, N$, respectively). As expected, all neurons in the SP of EGFP-AAV-injected mice showed endogenous CB expression. However, in HACB2-AAV transduced interneurons, $C B$ expression was noticeably stronger than the endogenous $\mathrm{CB}$ expression of either the surrounding non-transduced pyramidal neurons (Fig. 1M) or interneurons transduced with EGFP-AAV (Fig. $1 M$ vs $N$, $O$ vs $P$ ). Analysis of confocal images (Fig. 1O,P) revealed that HA MFI is significantly increased in HACB2-AAV transduced interneurons (CB: $133.3 \pm 11.7$ A.U.; EGFP: $25.3 \pm 1.1$ A.U.; Mann-Whitney $U$ test, $p=0.029$; Fig. 1Q) as is integrated fluorescence intensity of CB puncta (CB: $617.6 \pm 59.5$; EGFP: $428.3 \pm 42.6$ A.U.; Mann-Whitney $U$ test, $p=0.029$; Fig. $1 R$ ). While there was no change in the density of the clusters (Mann-Whitney $U$ test, $p=0.69$ ), there was a moderate but not significant increase in size of clusters (CB: $0.211 \pm 0.019 \mu \mathrm{m}^{2}$; EGFP: $0.161 \pm 0.008 \mu \mathrm{m}^{2}$ Mann-Whitney $U$ test, $p=0.057$ ).

\section{Conditional overexpression of HA-CB2SH3- in CA1 pyramidal neurons results in enhanced gephyrin and perisomatic GABAAR- $\boldsymbol{\gamma} \mathbf{2}$ clusters in VGLUT1-cre mice}

To investigate the extent to which overexpression of HA-CB2SH3- affects hippocampal GABAergic synapses, we examined presynaptic and postsynaptic protein expression in HACB2-AAV transduced glutamatergic pyramidal cells of CA1 (Fig. $2 A$ ), as compared with those transduced with EGFP-AAV (Fig. 2B). Because of the packed nature of the transduced hippocampal pyramidal cells, regions within CA1 were examined rather than individual transduced cells: ROls within the SP that contain the cell bodies of the pyramidal cells, or ROls within SO or SR populated by processes of the pyramidal cells. In VGLUT1-cre mice injected with the HACB2-AAV, there were significant increases in average size of gephyrin clusters in each region of the transduced CA1 (SO: CB: $0.343 \pm 0.015 \mu \mathrm{m}^{2}$, EGFP: $0.253 \pm 0.008 \mu \mathrm{m}^{2}$; SP: CB: $0.247 \pm 0.011 \mu \mathrm{m}^{2}$, EGFP: $0.195 \pm 0.008 \mu \mathrm{m}^{2}$; SR: CB: $0.288 \pm 0.014 \mu \mathrm{m}^{2}$, EGFP: $0.229 \pm 0.008 \mu \mathrm{m}^{2}$; MannWhitney $U$ test, $p=0.002, p=0.009, p=0.026$; respectively; Fig. 2C). The gephyrin clusters in these regions of HACB2-AAV-transduced CA1 also had increased MFI in the SO (32.4\% increase), SP (61.5\% increase), and SR (43.7\% increase) compared with EGFP-AAV-transduced 


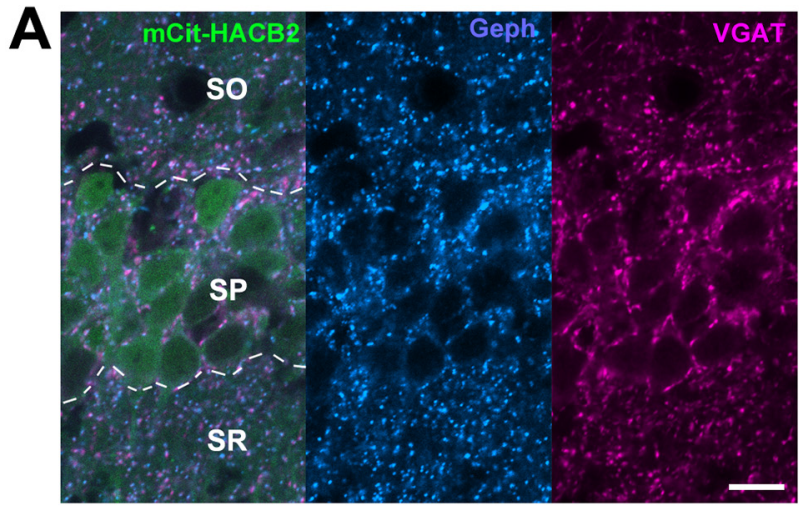

C

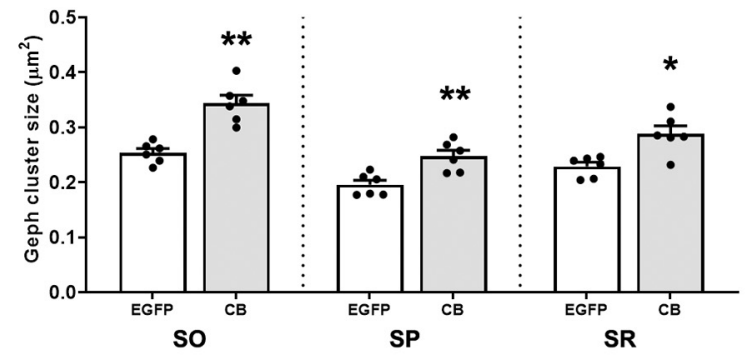

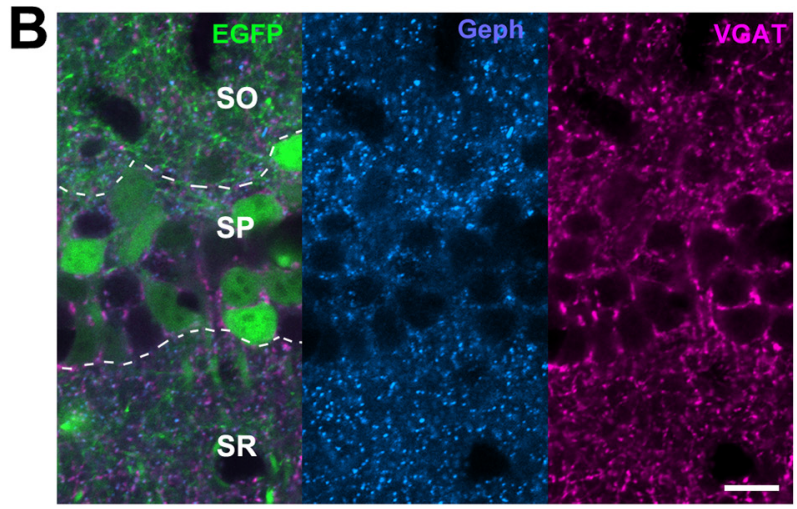

D

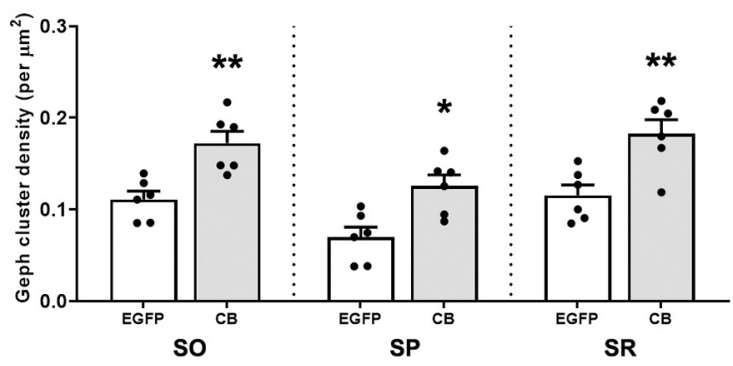

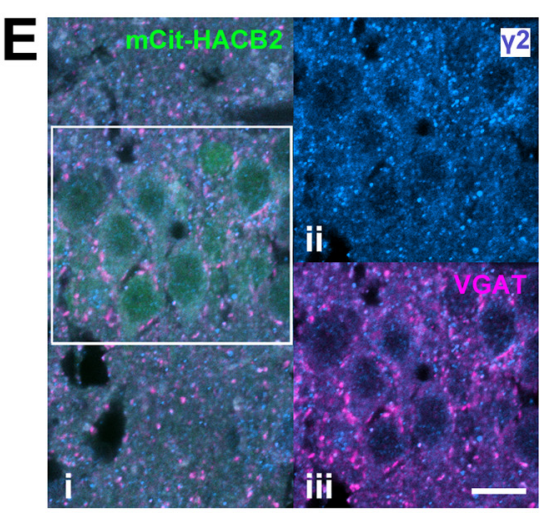

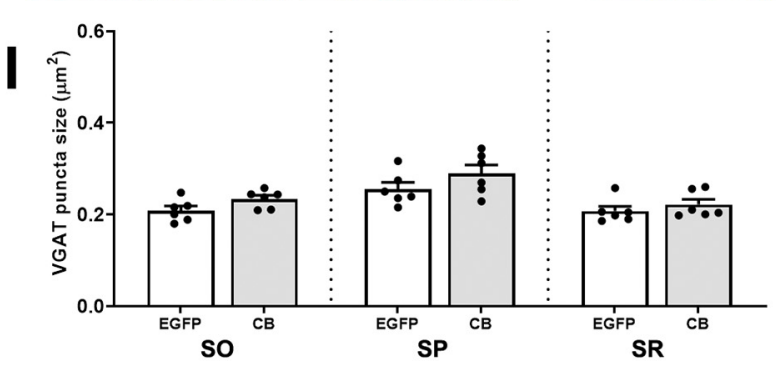

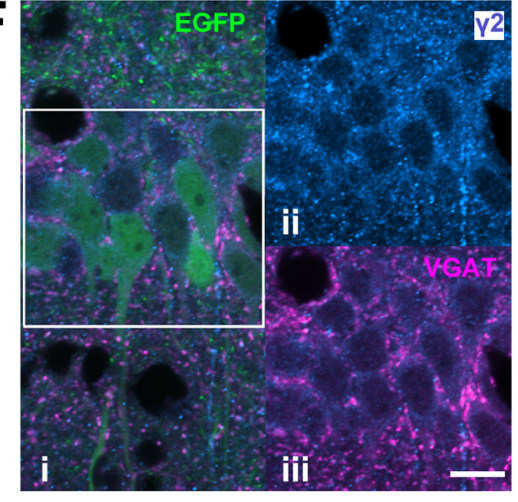

(2) $\mathbf{G}$
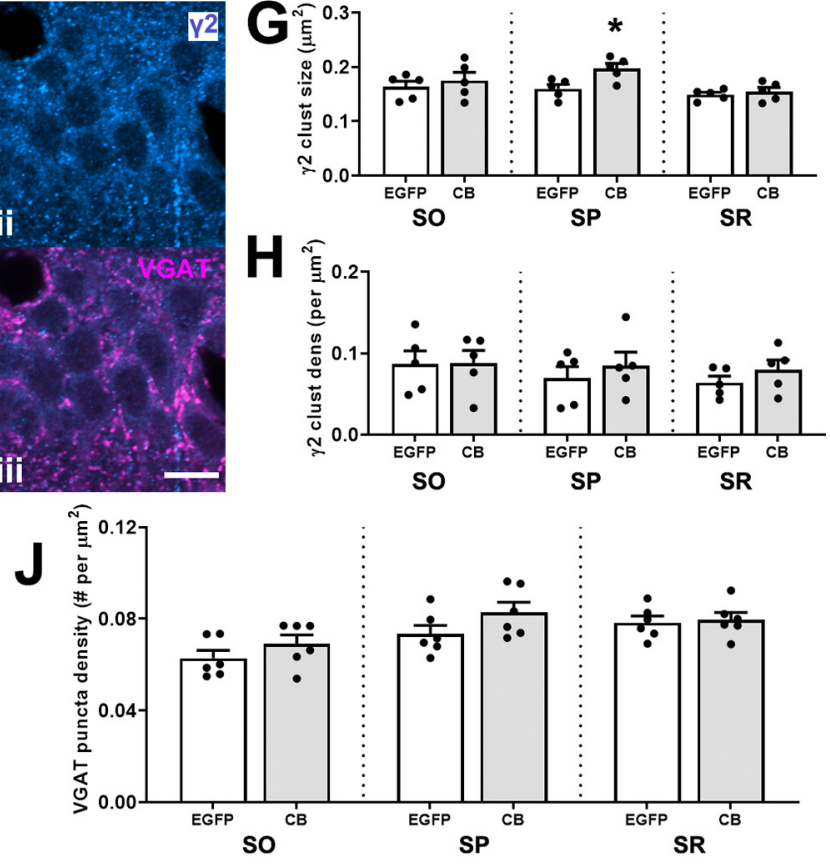

Figure 2. Overexpression of HA-CB2SH3- in hippocampal CA1 pyramidal cells of the VGLUT1-IRES-cre mouse results in larger postsynaptic gephyrin clusters without observed alteration of the presynaptic GABAergic input. $\boldsymbol{A}, \boldsymbol{B}$, Representative IF images of CA1 pyramidal cells transduced with mCitrine-HACB2-AAV $(\boldsymbol{A})$ or EGFP-AAV $(\boldsymbol{B})$ labeled with Ms anti-Geph (blue) and GP antiVGAT (magenta). Outlined in $\boldsymbol{A}, \boldsymbol{B}$ are rough borders for SO, SP, and SR. $\boldsymbol{C}, \boldsymbol{D}$, Quantification of size $(\boldsymbol{C})$ and density $(\boldsymbol{D})$ of gephyrin clusters in these regions. $\boldsymbol{E}, \boldsymbol{F}$, Representative IF images of CA1 pyramidal cells transduced with mCitrine-HACB2-AAV (E) or EGFPAAV $(\boldsymbol{F})$ labeled with Ms anti- $\gamma 2$ (blue; $\boldsymbol{i}, \boldsymbol{i}$ ) and GP anti-VGAT (magenta; $\boldsymbol{i}$, iii). Panels $\boldsymbol{i}$, iii show individual channels for blue and red for SP as outlined in the box in $\boldsymbol{i}$. $\boldsymbol{G}, \boldsymbol{H}$, Quantification of size $(\boldsymbol{G})$ and density $(\boldsymbol{H})$ of $\mathrm{GABA}_{\mathrm{A}} \mathrm{R} \gamma 2$ clusters in these regions. $\boldsymbol{I}$, $\boldsymbol{J}$, Quantification of size (I) and density ( $\boldsymbol{J})$ of VGAT puncta in these regions. Each dot represents the mean for quantification for one animal, and error bars indicate SEM. At least two sections were processed per animal, with three ROls in each region (SO, SP, SR) for each of five images for each hemisphere (total sampled area per region/hemisphere $=7500 \mu \mathrm{m}^{2}$ ). Scale bar: $10 \mu \mathrm{m}$. Asterisks in the quantification graphs indicate significance using Mann-Whitney $U$ test; ${ }^{*} p<0.05,{ }^{\star *} p<0.01$. 

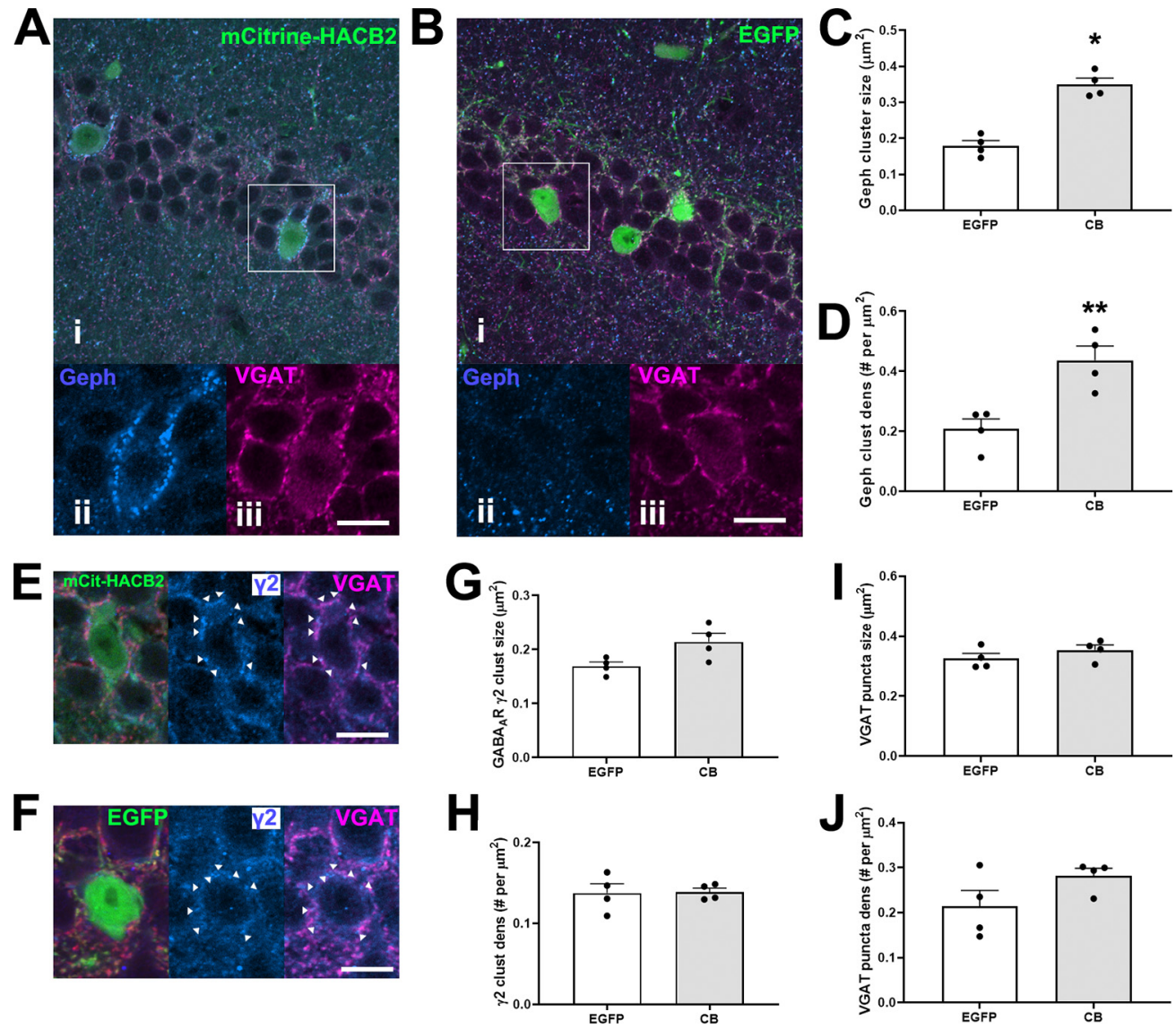

Figure 3. Overexpression of HA-CB2SH3- in hippocampal interneurons of the VGAT-IRES-cre mouse results in larger gephyrin clusters without observed alterations of presynaptic VGAT input. $\boldsymbol{A}, \boldsymbol{B}$, Representative IF images of CA1 interneurons transduced with mCitrine-HACB2-AAV $(\boldsymbol{A})$ or EGFP-AAV $(\boldsymbol{B})$ labeled with Ms anti-Geph (blue; ii) and GP anti-VGAT (magenta; iii). Inset of boxes in $\boldsymbol{i}$ are shown in ii, iii. $\boldsymbol{C}, \boldsymbol{D}$, Quantification of the size $(\boldsymbol{C})$ and density $(\boldsymbol{D})$ of the gephyrin clusters on the perimeter of the transduced cells. $\boldsymbol{E}, \boldsymbol{F}$, Representative IF images of CA1 interneurons transduced with mCitrine-HACB2-AAV (E) or EGFP-AAV $(\boldsymbol{F})$ labeled with $\mathrm{Rb}$ anti- $\gamma 2$ (blue; ii) and GP anti-VGAT (magenta; iii). $\mathbf{G}, \boldsymbol{H}$, The size $(\boldsymbol{G})$ and density $(\boldsymbol{H})$ of the GABA $\mathrm{A}_{\mathrm{A}} \mathrm{\gamma} 2$ clusters on the perimeter of the transduced cells were quantified. The size $(\boldsymbol{I})$ and density $(\boldsymbol{J})$ of the VGAT puncta surrounding the transduced cell have been quantified. Each dot represents one animal and error bars indicate SEM. Two sections per animal were processed and at least five cells per brain section were quantified. Scale bars: $20 \mu \mathrm{m}(\boldsymbol{A}, \boldsymbol{B} \boldsymbol{i})$ and $10 \mu \mathrm{m}(\boldsymbol{A}, \boldsymbol{B i i}, \boldsymbol{B} i i i, \boldsymbol{E}, \boldsymbol{F})$. Asterisks in the quantification graphs indicate significance using Mann-Whitney $U$ test; ${ }^{*} p<0.05$, ${ }^{* \star} p<0.01$.

CA1 (Mann-Whitney $U$ test, $p=0.026, p=0.004$, and $p=0.009$, respectively). There were also more clusters in these regions of transduced CA1 (SO: CB: $0.172 \pm 0.013$ per $\mu \mathrm{m}^{2}$, EGFP: $0.111 \pm 0.009$ per $\mu \mathrm{m}^{2}$; SP: CB: $0.126 \pm$ 0.012 per $\mu \mathrm{m}^{2}$, EGFP: $0.070 \pm 0.11$ per $\mu \mathrm{m}^{2}$; SR: CB: $0.183 \pm 0.015$ per $\mu \mathrm{m}^{2}$, EGFP: $0.116 \pm 0.011$ per $\mu \mathrm{m}^{2}$; Mann-Whitney $U$ test, $p=0.004, p=0.015$, and $p=0.015$; respectively; Fig. 2D). Size, density and MFI of gephyrin clusters were also increased compared with non-transduced contralateral hemisphere in the HACB2-AAV-injected mouse brains. There were no significant differences in any of the measured parameters between contralateral hemispheres of HACB2-AAV-injected mice and EGFP-AAV-injected mice.

In the SP of the HACB2-AAV-injected mice, there was also an increase of size of $\gamma 2 \mathrm{GABA}_{\mathrm{A}} \mathrm{R}$ subunit clusters compared with the EGFP-AAV-injected mice (CB: $0.197 \pm 0.009 \mu \mathrm{m}^{2}$ vs EGFP: $0.160 \pm 0.008 \mu \mathrm{m}^{2}$; Mann-Whitney $U$ test, $p=0.032$; Fig. 2E-H). No significant differences in $\mathrm{GABA}_{\mathrm{A}} \mathrm{R} \gamma 2$ density or MFI were detected in the SP. Moreover, no difference in cluster size, density or MFI were found in the SO or SR of HACB2-AAV versus EGFP-AAV-injected mice.

Regarding presynaptic VGAT expression, there was no significant change to puncta size, density, or MFI of the presynaptic VGAT in SO, SP or SR in the HACB2-AAV versus EGFP-AAV-injected mice (Fig. $2 l, J$ ).

\section{Conditional overexpression of HA-CB2SH3- enhances gephyrin clusters in CA1 interneurons in VGAT-cre mice}

We examined the changes to presynaptic and postsynaptic proteins at the GABAergic synapse as a result of overexpression of $\mathrm{HA}-\mathrm{CB} 2 \mathrm{SH} 3-$ in $\mathrm{CA} 1$ interneurons (Fig. $3 A$ ). There was a marked increase in the size of perisomatic gephyrin clusters on neurons transduced with the HACB2-AAV $\left(0.350 \pm 0.017 \mu \mathrm{m}^{2}\right)$ compared with those transduced with the EGFP-AAV $(0.179 \pm$ 
A
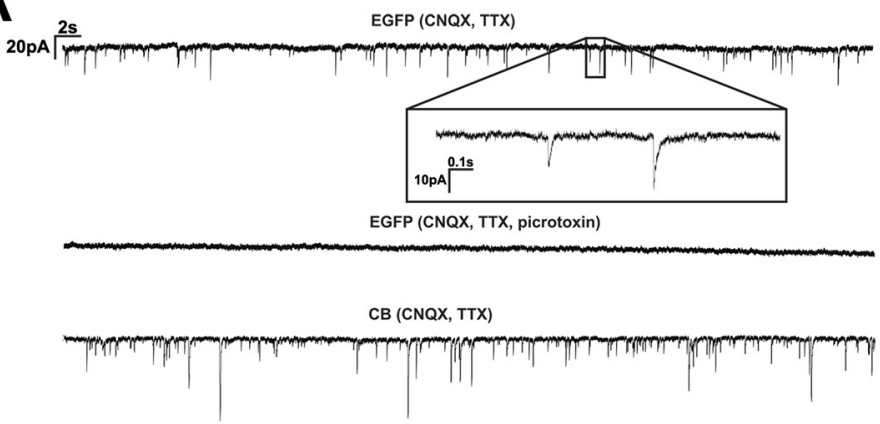

CB (CNQX, TTX, picrotoxin)
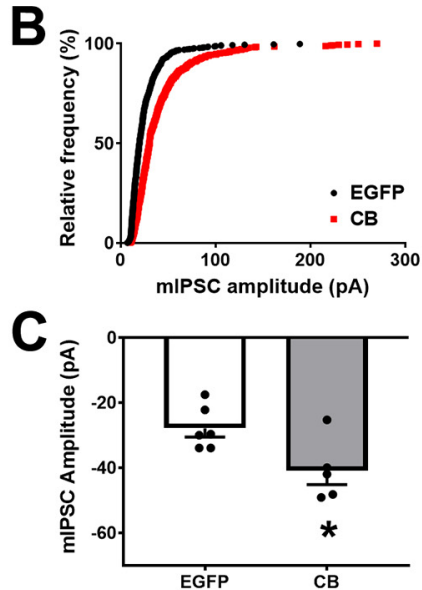
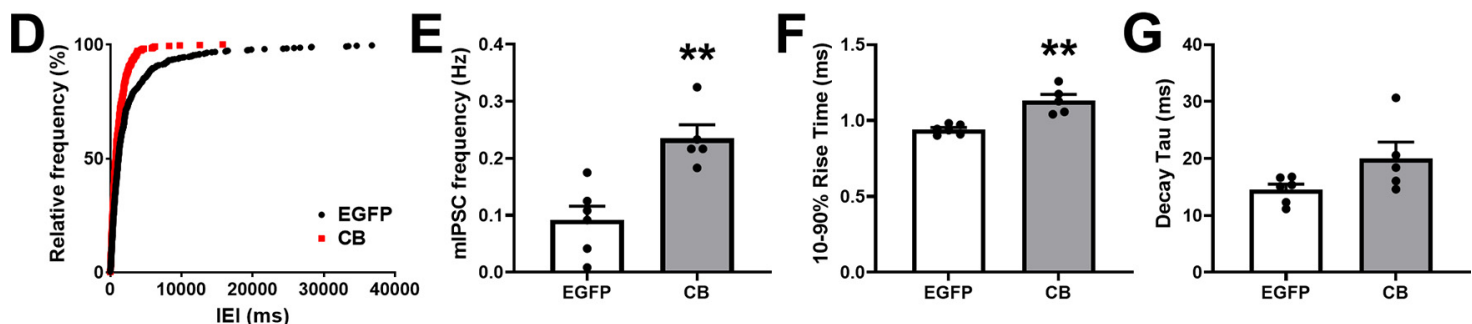

Figure 4. Pyramidal CA1 cells of the VGLUT1-IRES-cre mouse transduced with HACB2-AAV have increased strength of synaptic inhibitory neurotransmission. A, Representative traces showing mIPSCs from EGFP-AAV-transduced cells (top) or mCitrine-HACB2AAV-transduced cells (bottom) that were eliminated in the presence of picrotoxin (lower trace for each). Inset of upper trace shows stereotypical mIPSCs. Vertical scale bar indicates $20 \mathrm{pA}$ and horizontal bar indicates $2 \mathrm{~s}$. Inset, Vertical scale bar indicates $10 \mathrm{pA}$; while horizontal bar indicates $0.1 \mathrm{~s}$. B. Amplitudes of mIPSCs were quantified and the cumulative relative frequency displayed. $\boldsymbol{C}$, The average amplitudes of mIPSCs. $\boldsymbol{D}$, Interevent interval (IEI) of mIPSCs were quantified and the cumulative relative frequency displayed. $\boldsymbol{E}$, Quantification of the average frequency of mIPSCs. $\boldsymbol{F}, \boldsymbol{G}$, Quantification of the average $10-90 \%$ rise time $(\boldsymbol{F})$, and decay tau $(\boldsymbol{G})$. For $\boldsymbol{C}, \boldsymbol{E}-\boldsymbol{G}$, each dot represents one cell from which 100 events were quantified, and error bars indicate SEM. For $\boldsymbol{B}$, $\boldsymbol{D}$, Kolmogorov-Smirnov tests were performed; $p<0.001$. Asterisks indicate significance using Mann-Whitney $U$ test; ${ }^{\star} p<0.05$, ${ }^{* *} p<0.01$.

$0.015 \mu \mathrm{m}^{2}$; Mann-Whitney $U$ test, $p=0.029$; Fig. $\left.3 A-C\right)$ and a $140 \%$ increase in MFI of clusters (Mann-Whitney $U$ test, $p=0.029$ ). This was accompanied by an increase in the density of gephyrin clusters in neurons transduced with HACB2-AAV compared with EGFP-AAV $\left(0.436 \pm 0.047\right.$ and $0.207 \pm 0.034$ clusters $/ \mu \mathrm{m}^{2}$, respectively; Mann-Whitney $U$ test, $p=0.029$; Fig. $3 D$ ). Despite gephyrin clusters in HACB2-AAV transduced interneurons being nearly twice the size, and twice as numerous as in EGFP-AAV transduced interneurons, there was only a modest, but not significant, increase in the size of $\mathrm{GABA}_{A} \mathrm{R} \gamma 2$ clusters (CB: $0.214 \pm 0.016$ vs EGFP: $0.169 \pm 0.008 \mu \mathrm{m}^{2}$; Mann-Whitney $U$ test, $p=0.057$; Fig. $3 E-G)$ and no significant change in density of clusters (CB: $0.139 \pm 0.005$ vs EGFP: $0.138 \pm 0.011$ puncta $/ \mu m^{2}$; Mann-Whitney $U$ test, $p>0.99$; Fig. $3 H$ ).

There were no corresponding changes in either size (CB: $0.353 \pm 0.017 \mu \mathrm{m}^{2}$; EGFP: $0.325 \pm 0.017 \mu \mathrm{m}^{2}$; Mann-Whitney $U$ test, $p=0.34$; Fig. $3 /$ ) or density (CB: $0.282 \pm 0.017$ puncta/ $/ \mathrm{m}^{2}$; EGFP: $0.214 \pm 0.036$ puncta/ $\mu \mathrm{m}^{2}$; Mann-Whitney $U$ test, $p=0.49$; Fig. $3 J$ ) in VGATpositive terminals synapsing onto transduced cells. Additionally, there were no differences in overall gephyrin, $\mathrm{GABA}_{\mathrm{A}} \mathrm{R} \gamma 2$, or VGAT cluster size or density in the contralateral CA1 between HACB2-AAV-injected and EGFP-AAV-injected mice.

\section{Synaptic inhibitory neurotransmission is strengthened in HA-CB2SH3- overexpressing CA1 pyramidal neurons}

To determine whether the enlarged gephyrin and $\mathrm{GABA}_{A} R$ clusters in VGLUT1-cre mice transduced with HACB2-AAV corresponded to stronger synaptic inhibitory neurotransmission, we measured spontaneous mIPSCs in transduced CA1 pyramidal neurons in brain slices from mice bilaterally injected with either HACB2-AAV or control EGFP-AAV. We found that in HACB2-AAV transduced CA1 pyramidal cells, there were more inhibitory events, many with higher amplitudes than in the control EGFPAAV-transduced cells (Fig. 4A). These mIPSCs were eliminated in the presence of picrotoxin, ascertaining that they correspond to $\mathrm{GABA}_{A} \mathrm{R}$ currents.

A cumulative relative frequency plot indicates a right shift in the amplitudes of mIPSCs in HACB2-AAV-transduced neurons (Kolmogorov-Smirnov $p<0.001$; Fig. $4 B$ ) and greater amplitudes (CB: $-40.91 \pm 4.28 \mathrm{pA}$; EGFP: $-27.88 \pm 2.71 \mathrm{pA}$; Mann-Whitney $U$ test, $p=0.046$; Fig. $4 C$ ), suggesting an increase in the number of postsynaptic $G A B A_{A} R s$. 
The mIPSCs in HACB2-AAV-transduced cells shifted to lower interevent intervals (Kolmogorov-Smirnov, $p<0.001$; Fig. $4 D$ ) and these transduced neurons demonstrated higher frequencies (CB: $0.537 \pm 0.095 \mathrm{~Hz}$; EGFP: $0.181 \pm 0.036 \mathrm{~Hz}$; Mann-Whitney $U$ test, $p=0.004$; Fig. $4 E$ ) than control EGFP-AAV cells. This finding when taken together with our results demonstrating no change in size or density of presynaptic VGAT, likely indicates a higher probability of release from presynaptic GABAergic terminals. Finally, we analyzed the rise time and decay tau of mIPSCs, to determine whether there might be any changes in receptor kinetics which might speak to alterations in distribution of receptors or receptor subunit composition. We found that while there was a significant increase in 1090\% rise times of mIPSCs in HACB2-AAV neurons (CB: $1.132 \pm 0.040 \mathrm{~ms}$; EGFP: $0.941 \pm 0.013 \mathrm{~ms}$; Mann-Whitney $U$ test, $p=0.004$; Fig. $4 F$ ), the increase in decay tau was not significant (CB: $20.05 \pm 2.84 \mathrm{~ms}$; EGFP: $14.55 \pm 0.95 \mathrm{~ms}$; Mann-Whitney $U$ test, $p=0.126$; Fig. $4 G$ ).

\section{VGLUT1-cre mice injected with HACB2-AAV are less susceptible to acute seizures}

To determine whether increased GABAergic inhibitory synaptic neurotransmission in CA1 pyramidal cells, seen in VGLUT1-cre mice injected with the HACB2-AAV, imparted neuroprotective effects against acute seizures, we subjected AAV-injected mice to intraperitoneal injections of PTZ. Based on initial studies we settled on a dose of PTZ $(40 \mathrm{mg} / \mathrm{kg})$, which induced seizures reliably in naive animals with minimal mortality. Three weeks after bilateral CA1 injection with HACB2-AAV ( $n=15$ mice) or a control EGFP-AAV ( $n=12$ mice), we assessed seizures along a modified Racine scale after a single dose of PTZ. The mice injected with the HACB2-AAV displayed lower cumulative seizure scores over the 30 min observed, compared with the EGFP-AAV control mice (KolmogorovSmirnov test, $p<0.001$; Fig. 5A). HACB2-AAV-injected mice were less likely to have higher intensity seizures after PTZ compared with the control mice (Fisher's exact, $p=0.020, p=0.019$, and $p=0.002$; seizure scores 4,5 , and 6 , respectively; Fig. $5 B$ ). When comparing the onset latency to the first seizure of each intensity score (Fig. $5 C$ ), we found an increased latency period for the HACB2-AAV mice for seizure scores 1 and 2 (CB: $216.1 \pm 16.6$ s, EGFP: $76.4 \pm 2.6 s$; and CB: $260.0 \pm 22.4$ s, EGFP: $83.3 \pm 2.8 \mathrm{~s}$; unpaired $t$ test, $p=0.031$ and $p=$ 0.042 , respectively). However, the increased latency times were not statistically significant at the higher seizure scores because of the low numbers of HACB2AAV mice having high intensity seizures (note the diminishing number of data points in Fig. $5 C$ ).

\section{Discussion}

We evaluated the effects of overexpressing CB in specific neuron types in the adult dorsal hippocampus. While $\mathrm{CBSH} 3+$ splice variants are the far more abundantly expressed isoforms of CB (Harvey et al., 2004), they are autoinhibited in their ability to induce clustering of gephyrin, unless relieved by other postsynaptic proteins (Poulopoulos et al., 2009; Mayer et al., 2013; Soykan et
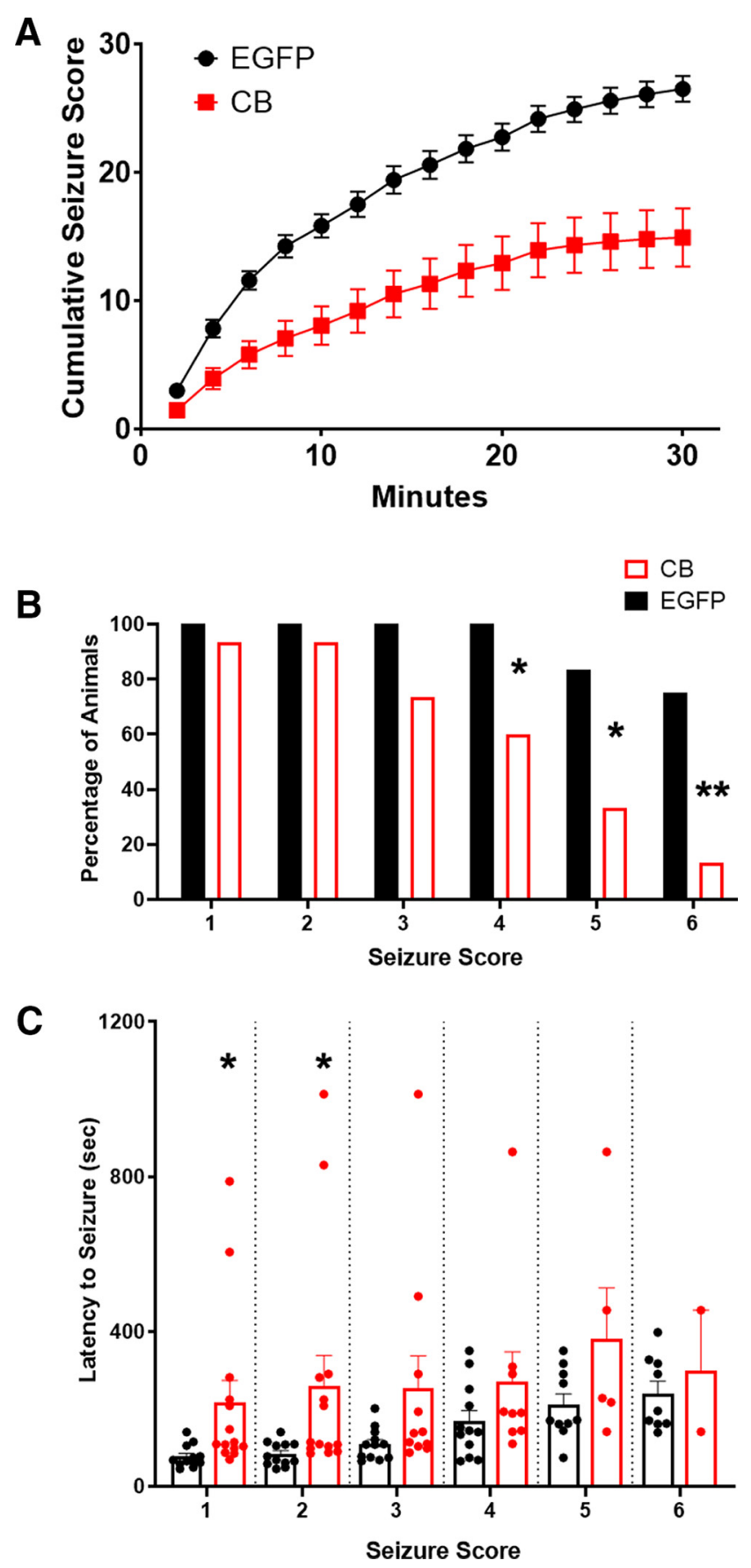

Figure 5. VGLUT1-IRES-cre mouse injected intrahippocampally with mCitrine-HACB2-AAV display lower susceptibility to PTZinduced intense seizures. $\boldsymbol{A}$, Seizures were scored along a modified Racine scale and a maximal seizure score assigned in 2-min bins, and average cumulative scores are presented. $\boldsymbol{B}$, The percentage of animals that had a seizure at each intensity score. Asterisks indicate significance using Fisher's exact test; ${ }^{*} p<0.05,{ }^{* *} p<0.01$. C , The average latency to the first seizure of each intensity was recorded. Error bars indicate SEM, and each dot represents one animal. Note that at higher intensity seizure scores, there are fewer mice that seize, particularly in the $\mathrm{CB}$ category. Most mice seize with lower intensities. Asterisks indicate significance using unpaired $t$ test; ${ }^{*} p<0.05$. 
al., 2014). The constitutively active CBSH3- isoforms, however, are capable of inducing the accumulation of gephyrin and $\mathrm{GABA}_{\mathrm{A}}$ Rs at postsynaptic sites (Chiou et al., 2011; Tyagarajan et al., 2011; Fekete et al., 2017). We found that overexpression of $\mathrm{CB} 2 \mathrm{SH} 3-$ in hippocampal CA1 pyramidal neurons resulted in significantly increased $C B$, gephyrin and $G A B A_{A} R$ clustering in perisomatic regions (within SP). Overexpression of CB2SH3- in CA1 interneurons also resulted in increased $C B$ expression, and larger perisomatic gephyrin and $\mathrm{GABA}_{\mathrm{A}} \mathrm{R}$ clusters. The increase in postsynaptic GABAergic receptors was accompanied by a significantly increased mIPSC amplitude and frequency. Overexpression of CB2SH3- in excitatory neurons in CA1 of the dorsal hippocampus also provided resilience against PTZ-induced seizures.

In CA1 pyramidal cells, overexpression of CB2SH3- resulted in an increase in gephyrin and $\mathrm{GABA}_{A} \mathrm{R}$ cluster size. The majority of these large gephyrin clusters were apposed to VGAT terminals, indicating localization to GABAergic synapses. This is consistent with what has been seen in cultured hippocampal neurons transfected to overexpress CB2SH3- (Chiou et al., 2011; Tyagarajan et al., 2011; Körber et al., 2012) and in CB2SH3- transfected pyramidal neurons of the cerebral cortex of in utero electroporated (IUE) rats (Fekete et al., 2017). In HACB2AAV transduced hippocampal pyramidal cells, the increase in amplitude of spontaneous mIPSCs further indicates an accumulation of $\mathrm{GABA}_{\mathrm{A}} \mathrm{Rs}$ at the postsynapse.

Immunofluorescence revealed an increase in synaptic $\gamma 2$-containing $\mathrm{GABA}_{A} \mathrm{Rs}$ in SP, but not in SO or SR, despite CA1 pyramidal cells receiving $92 \%$ of their GABAergic synaptic input at their dendrites (Megías et al., 2001). Each cell compartment is typically innervated by different interneuron subtypes, with parvalbumin $(\mathrm{PV})+$ and cholecystokinin $(\mathrm{CCK})+$ basket cells providing the majority of GABAergic innervation to perisomatic regions (Miles et al., 1996; Salesse et al., 2011). In addition, PV + chandelier cells almost exclusively innervate the axon initial segments of pyramidal cells, which lie at the border of SP and SO (Buhl et al., 1994). The increased $\mathrm{GABA}_{A} R \quad \gamma 2$ clustering in SP suggests that the perisomatic synapses, in particular, are strengthened by HACB2-AAV transduction, although the longer rise times of spontaneous mIPSCs raise the possibility of increased $G A B A_{A} R$ clustering at more distal synapses, or the addition of $G A B A_{A} R s$ of alternative compositions to the perisomatic synapses. At these synapses, $\mathrm{GABA}_{\mathrm{A}} \mathrm{Rs}$ predominantly have $\alpha 1 \beta 3 \gamma 2$ and $\alpha 2 \beta 3 \gamma 2$ subunit composition (Nusser et al., 1996; Nyíri et al., 2001; Kasugai et al., 2010). The increase in postsynaptic gephyrin cluster size might attract extrasynaptic $\alpha 5 \beta 3 \gamma 2$ GABA $_{\mathrm{A}}$ Rs into the postsynapse. The $\alpha 5 \beta 3 \gamma 2 \mathrm{GABA}_{\mathrm{A}}$ Rs are mostly extrasynaptic but can also be synaptically localized (Brünig et al., 2002; Christie et al., 2002; Schweizer et al., 2003; Alldred et al., 2005; Serwanski et al., 2006). The incorporation of $\alpha 5 \beta 3 \gamma 2 \mathrm{GABA}_{\mathrm{A}} \mathrm{Rs}$ into the synapse is consistent with the longer rise times and very slow deactivation of $\alpha 5 \beta 3 \gamma 2 \mathrm{GABA}_{\mathrm{A}} \mathrm{Rs}$ compared with $\alpha 1 \beta 3 \gamma 2$ and $\alpha 2 \beta 3 \gamma 2$ (Mortensen et al., 2012). In hippocampal pyramidal neurons, the $\alpha 5, \alpha 2$, and $\alpha 1$ are the three most abundant $\alpha \mathrm{GABA}_{\mathrm{A}} \mathrm{R}$ subunits, in that order (Wisden et al., 1992; Fritschy and Mohler, 1995; Nusser et al., 1996; Brünig et al., 2002; Serwanski et al., 2006; Kasugai et al., 2010). Immunofluorescence revealed that the effects of HACB2$A A V$ on enhancing postsynaptic $\mathrm{GABA}_{\mathrm{A}} \mathrm{R}$ clustering are more subdued than the effects on gephyrin clustering. We attribute it to the fact that gephyrin clustering in these cells is largely concentrated on GABAergic synapses, while $\gamma 2$ containing $\mathrm{GABA}_{\mathrm{A}} \mathrm{Rs}$ are both synaptic and extrasynaptic.

We did not observe any changes in density, MFI, or size of VGAT puncta, which is consistent with previous studies indicating that $\mathrm{CB}$ is not synaptogenic: knocking out $\mathrm{CB}$ in mice, while disruptive of gephyrin clusters in certain brain regions, does not affect presynaptic GABAergic innervation (Papadopoulos et al., 2007), nor does knockdown of CBSH3- or CBSH3+ isoforms (George et al., 2021) or overexpression of CB (Chiou et al., 2011; Fekete et al., 2017). Nevertheless, we observed a left-shift in interevent interval and increase in frequency of mIPSCs in CB2SH3- overexpressing cells. Since this is not accompanied by increased presynaptic GABAergic innervation, as shown by VGAT immunofluorescence, the result is consistent with an increased probability of spontaneous vesicular GABA release from presynaptic terminals onto HACB2-AAV-transduced cells. Therefore, increased postsynaptic clustering of gephyrin/GABA $A_{A}$ Rs seems to have a transsynaptic effect on spontaneous GABA release. $\mathrm{PV}+$ and $\mathrm{CCK}+$ basket cells in the hippocampus have distinct mechanisms for modulating presynaptic release. While CCK + basket cell terminals are covered in cannabinoid and $\mathrm{GABA}_{B}$ Rs (Marsicano and Lutz, 1999; Sloviter et al., 1999; Liu et al., 2019), $\mathrm{M}_{2}$ muscarinic and $\mu$-opioid receptors modulate activity at $\mathrm{PV}+$ basket cell terminals (Hájos et al., 1998; Drake and Milner, 2006; Freund and Katona, 2007). The increase in spontaneous mIPSC frequency is contrary to the decreased frequency observed in pyramidal cells of rat cerebral cortex transfected by IUE to overexpress CB2SH3- (Fekete et al., 2017). This difference could be attributed to: (1) being neurons in different brain areas innervated by different interneurons; or (2) the IUE study involved CB2SH3- overexpression in a sparse population of pyramidal neurons in cerebral cortex since embryonic age, which has the potential for altering synaptic function in the adult.

The possibility of enhancing synaptic GABAergic neurotransmission in hippocampal circuits is of particular interest in regards to circuits in which there is an excitation/ inhibition imbalance. In the current study, we used the chemoconvulsant PTZ to induce acute seizures. The mechanism of action for PTZ is not well understood, but it has been demonstrated to cause calcium and sodium influx in neurons, thereby resulting in depolarization (Papp et al., 1987). PTZ been used to model acute seizures with a single dose, and to study epileptogenesis in chemical kindling models with multiple subthreshold doses. In VGLUT1-cre mice injected with HACB2-AAV, latency to PTZ-induced seizure events was increased and mice were less likely to develop severe seizures, thereby demonstrating that enhancing the strength of GABAergic synaptic inhibition through HACB2-AAV transduction provided 
protection against convulsions. Our results bring attention to $\mathrm{CB}$ as a possible target for therapeutic intervention. They suggest that enhancing $\mathrm{CB}$ expression or enhancing the activity of existing endogenous $\mathrm{CB}$ in a selected population of hyperactive hippocampal neurons may decrease their activity and prove useful in ameliorating seizures originating in hippocampal structures such as temporal lobe epilepsy.

In VGAT-cre mice, we quantified interneurons with soma residing within the SP. While the majority of these cells are PV + basket cells, there are many additional interneuron types whose soma can be found within or immediately adjacent to the SP, including CCK + basket cells, PV + bistratified or chandelier cells, ivy cells, and vasointestinal active peptide (VIP) + type 1 or three interneuron selective interneurons (Klausberger, 2009; Pelkey et al., 2017). Many additional interneuron types were transduced in the SO and SR that may be bistratified cells, oriens-lacunosum moleculare cells, or $\mathrm{CCK}+$ I VIP + basket cells (Sik et al., 1995; Baude et al., 2007). The vast majority of boutons from pyramidal layer interneurons terminate on pyramidal cells within the SP or onto the soma of other basket cells or bistratified cells within the SP (Sik et al., 1995; Földy et al., 2010). CB may be differentially expressed between various interneuron types. It has been shown that PV + interneurons in the hippocampus and cerebral cortex contain higher levels of endogenous CB (Arhgef9) transcripts and protein than other interneurons (Paul et al., 2017; George et al., 2021). We found that transduction with the HACB2-AAV resulted in increased expression of CB in transduced interneurons compared with control EGFPAAV transduced interneurons.

Transduction of interneurons with HACB2-AAV resulted in roughly two-fold increases in both size and density of perisomatic gephyrin and modest increases in perisomatic $\mathrm{GABA}_{A} R$ clusters. This effect was not accompanied by any changes to size, density, or MFI of presynaptic VGAT input onto the soma, indicating that $\mathrm{CBSH} 3-$ overexpression does not recruit additional GABAergic innervation to these cells. To maintain consistency in our analysis, we restricted ourselves to quantification in cells within the center of SP. However, nearly every HACB2-AAV-transduced CA1 interneuron, including those in SO and on the perimeter of SR, displayed a noticeably strong perisomatic ring of gephyrin clusters. This was rarely seen in non-transduced interneurons of the contralateral CA1 or in EGFP-AAV-transduced CA1 interneurons. However, strong diffuse or punctate extrasynaptic immunoreactivity with the $\mathrm{GABA}_{A} R \mathrm{R}_{2}$ antibody was frequently seen in CA1 interneurons, in VGAT-cre as well as VGLUT1-cre mice, and in both HACB2-AAV and EGFP-AAV injected and non-injected hemispheres, indicating that the $\gamma 2$-containing $\mathrm{GABA}_{A} R s$ in interneurons are not only synaptic but also extrasynaptic.

The results of HACB2-AAV injection in VGAT-cre mice indicates that our approach can also be used for targeting GABAergic interneurons for the conditional overexpression of CB2SH3-. However, because of the heterogeneity of the transduced interneurons and the diversity of synaptic inhibitory GABAergic inputs from other interneurons, the VGAT-cre mice are not adequate to properly interrogate the functional outcomes, which would be hard if not impossible to interpret. Instead, CB overexpression can be tailored to target-specific classes of interneurons in the hippocampus or any region of the brain by using selected interneuron-type-specific cre-driver mouse lines (i. e., PV-cre, CCK-cre, Calbindin2-cre, SOM-Cre, and VIPcre among others). These future studies are beyond the scope of this article.

Enhancement of inhibitory synapses have also been accomplished by overexpression of NL2, a cell-adhesion molecule found selectively at inhibitory postsynapses which interacts with and activates $\mathrm{CBSH} 3+$ (Poulopoulos et al., 2009; Soykan et al., 2014). It has also been demonstrated to interact with gephyrin and CB forming a tri-partite complex at GABAergic synapses with $\mathrm{GABA}_{A} \mathrm{R}-\gamma 2$ and the transmembrane $\mathrm{GABA}_{A} \mathrm{R}$ accessory protein LHFPL4 or GARLH (Varoqueaux et al., 2004; Davenport et al., 2017; Yamasaki et al., 2017). Two studies have investigated AAV-mediated overexpression of NL2 in the hippocampus. In one study, overexpression of NL2 results in increased gephyrin clusters and VGAT+ puncta by confocal microscopy immunofluorescence and an increase in the gephyrin, VGAT and $\mathrm{GABA}_{\mathrm{A}} \mathrm{R}-\gamma 2$ subunit protein expression by western blot, suggesting a strengthening inhibitory synapses in the transduced neurons (Van Zandt et al., 2019). In the other study, increased NL2 expression leads to increased mRNA levels for GAD65, but no increase in neurexin-1, gephyrin, or GAD67 mRNAs (Kohl et al., 2013). Interestingly, the two AAV-mediated NL2-overexpression studies also revealed alterations to behavior, notably, reductions in social aggression and dominance behaviors but also diminished preference for social novelty. In another study, overexpression of NL2 in cortical pyramidal neurons after in utero electroporation shows an increase in VGAT which were associated to gephyrin clusters (Fekete et al., 2015). An increase in VGAT, but no change in gephyrin was reported in transgenic animals overexpressing NL2 (Hines et al., 2008). In the same study, it was determined that pyramidal neurons in the prefrontal cortex of these transgenic mice had increased mIPSC frequency but showed no effect on the amplitude of mIPSCs (Hines et al., 2008; Fekete et al., 2015). It is worth noting that in the two AAV-NL2 studies, NL2 was simultaneously overexpressed in both glutamatergic and GABAergic neurons. The NL2 overexpression studies strongly suggest that NL2 overexpression in neurons enhances GABAergic synaptic transmission and that if targeted to specific neurons might also be effective for seizure suppression.

The HACB2-AAV and described methodology can be generally applied for selective in vivo enhancement of GABAergic synaptic transmission in any neuronal type and brain region, by using the expanding collection of available Cre-driver mouse lines. Moreover, our DIO-AAV could also be used for the overexpression of $\mathrm{CBSH} 3-$ in selected types of neurons in wild-type non-transgenic animal species besides mouse, by co-injecting it with another AAV carrying Cre-recombinase under the control of a neuron-type-specific modified promoter. This has been 
accomplished in rat and monkey (Mikhailova et al., 2016; Stauffer et al., 2016; Zalocusky et al., 2016).

\section{References}

Aarabi M, Kessler E, Madan-Khetarpal S, Surti U, Bellissimo D, Rajkovic A, Yatsenko SA (2019) Autism spectrum disorder in females with ARHGEF9 alterations and a random pattern of $X$ chromosome inactivation. Eur J Med Genet 62:239-242.

Alldred MJ, Mulder-Rosi J, Lingenfelter SE, Chen G, Luscher B (2005) Distinct gamma2 subunit domains mediate clustering and synaptic function of postsynaptic GABAA receptors and gephyrin. J Neurosci 25:594-603.

Baude A, Bleasdale C, Dalezios Y, Somogyi P, Klausberger T (2007) Immunoreactivity for the GABAA receptor alpha1 subunit, somatostatin and Connexin36 distinguishes axoaxonic, basket, and bistratified interneurons of the rat hippocampus. Cereb Cortex 17:2094-2107.

Bhat G, LaGrave D, Millson A, Herriges J, Lamb AN, Matalon R (2016) Xq11.1-11.2 deletion involving ARHGEF9 in a girl with autism spectrum disorder. Eur J Med Genet 59:470-473.

Brünig I, Scotti E, Sidler C, Fritschy JM (2002) Intact sorting, targeting, and clustering of gamma-aminobutyric acid A receptor subtypes in hippocampal neurons in vitro. J Comp Neurol 443:43-55.

Buhl EH, Halasy K, Somogyi P (1994) Diverse sources of hippocampal unitary inhibitory postsynaptic potentials and the number of synaptic release sites. Nature 368:823-828.

Charych EI, Yu W, Miralles CP, Serwanski DR, Li X, Rubio M, De Blas AL (2004a) The brefeldin A-inhibited GDP/GTP exchange factor 2, a protein involved in vesicular trafficking, interacts with the beta subunits of the GABA receptors. J Neurochem 90:173-189.

Charych El, Yu W, Li R, Serwanski DR, Miralles CP, Li X, Yang BY, Pinal N, Walikonis R, De Blas AL (2004b) A four PDZ domain-containing splice variant form of GRIP1 is localized in GABAergic and glutamatergic synapses in the brain. J Biol Chem 279:3897838990.

Chiou T, Bonhomme B, Jin H, Miralles CP, Xiao H, Fu Z, Harvey RJ, Harvey K, Vicini S, De Blas AL (2011) Differential regulation of the postsynaptic clustering of gamma-aminobutyric acid type A (GABAA) receptors by collybistin isoforms. J Biol Chem 286:22456-22468.

Chiou TT, Long P, Schumann-Gillett A, Kanamarlapudi V, Haas SA, Harvey K, O'Mara ML, De BA, Kalscheuer VM, Harvey RJ (2019) Mutation p.R356Q in the collybistin phosphoinositide binding site is associated With mild intellectual disability. Front Mol Neurosci 12:60.

Christie SB, De Blas AL (2003) GABAergic and glutamatergic axons innervate the axon initial segment and organize GABA(A) receptor clusters of cultured hippocampal pyramidal cells. J Comp Neurol 456:361-374.

Christie SB, Li R-W, Miralles CP, Riquelme R, Yang BY, Charych E, Wendou Y, Daniels SB, Cantino ME, De Blas AL (2002) Synaptic and extrasynaptic GABAA receptor and gephyrin clusters. Prog Brain Res 136:157-180.

Davenport EC, Pendolino V, Kontou G, McGee TP, Sheehan DF, López-Doménech G, Farrant M, Kittler JT (2017) An essential role for the tetraspanin LHFPL4 in the cell-type-specific targeting and clustering of synaptic $\mathrm{GABA}_{\mathrm{A}}$ receptors. Cell Rep 21:70-83.

Drake CT, Milner TA (2006) Mu opioid receptors are extensively colocalized with parvalbumin, but not somatostatin, in the dentate gyrus. Neurosci Lett 403:176-180.

Fekete CD, Chiou TT, Miralles CP, Harris RS, Fiondella CG, Loturco $\mathrm{JJ}$, De Blas AL (2015) In vivo clonal overexpression of neuroligin 3 and neuroligin 2 in neurons of the rat cerebral cortex: differential effects on GABAergic synapses and neuronal migration. J Comp Neurol 523:1359-1378.

Fekete CD, Goz RU, Dinallo S, Miralles CP, Chiou TT, Bear J Jr, Fiondella CG, LoTurco JJ, De Blas AL (2017) In vivo transgenic expression of collybistin in neurons of the rat cerebral cortex. $\mathrm{J}$ Comp Neurol 525:1291-1311.

Földy C, Lee SH, Morgan RJ, Soltesz I (2010) Regulation of fast-spiking basket cell synapses by the chloride channel CIC-2. Nat Neurosci 13:1047-1049.

Freund TF, Katona I (2007) Perisomatic inhibition. Neuron 56:33-42.

Fritschy JM, Mohler H (1995) GABAA-receptor heterogeneity in the adult rat brain: differential regional and cellular distribution of seven major subunits. J Comp Neurol 359:154-194.

George S, Bear J Jr, Taylor MJ, Kanamalla K, Fekete CD, Chiou TT, Miralles CP, Papadopoulos T, De Blas AL (2021) Collybistin SH3protein isoforms are expressed in the rat brain promoting gephyrin and GABA-A receptor clustering at GABAergic synapses. J Neurochem 157:1032-1051.

Grosskreutz Y, Hermann A, Kins S, Fuhrmann JC, Betz H, Kneussel M (2001) Identification of a gephyrin-binding motif in the GDP/GTP exchange factor collybistin. Biol Chem 382:1455-1462.

Hájos N, Papp EC, Acsády L, Levey AI, Freund TF (1998) Distinct interneuron types express $\mathrm{m} 2$ muscarinic receptor immunoreactivity on their dendrites or axon terminals in the hippocampus. Neuroscience 82:355-376.

Harvey K, Duguid IC, Alldred MJ, Beatty SE, Ward H, Keep NH, Lingenfelter SE, Pearce BR, Lundgren J, Owen MJ, Smart TG, Luscher B, Rees MI, Harvey RJ (2004) The GDP-GTP exchange factor collybistin: an essential determinant of neuronal gephyrin clustering. J Neurosci 24:5816-5826.

Hines RM, Wu L, Hines DJ, Steenland H, Mansour S, Dahlhaus R, Singaraja RR, Cao X, Sammler E, Hormuzdi SG, Zhuo M, ElHusseini A (2008) Synaptic imbalance, stereotypies, and impaired social interactions in mice with altered neuroligin 2 expression. $J$ Neurosci 28:6055-6067.

Jin $\mathrm{H}$, Chiou TT, Serwanski DR, Miralles CP, Pinal N, De Blas AL (2014) Ring finger protein 34 (RNF34) interacts with and promotes gamma-aminobutyric acid type-A receptor degradation via ubiquitination of the gamma2 subunit. J Biol Chem 289:29420-29436.

Kalscheuer VM, Musante L, Fang C, Hoffmann K, Fuchs C, Carta E, Deas E, Venkateswarlu K, Menzel C, Ullmann R, Tommerup N, Dalprà L, Tzschach A, Selicorni A, Lüscher B, Ropers HH, Harvey K, Harvey RJ (2009) A balanced chromosomal translocation disrupting ARHGEF9 is associated with epilepsy, anxiety, aggression, and mental retardation. Hum Mutat 30:61-68.

Kasugai Y, Swinny JD, Roberts JD, Dalezios Y, Fukazawa Y, Sieghart W, Shigemoto R, Somogyi P (2010) Quantitative localisation of synaptic and extrasynaptic GABAA receptor subunits on hippocampal pyramidal cells by freeze-fracture replica immunolabelling. Eur J Neurosci 32:1868-1888.

Khan ZU, Gutiérrez A, De Blas AL (1994) Short and long form gamma 2 subunits of the GABAA/benzodiazepine receptors. J Neurochem 63:1466-1476.

Kins S, Betz H, Kirsch J (2000) Collybistin, a newly identified brainspecific GEF, induces submembrane clustering of gephyrin. Nat Neurosci 3:22-29.

Klausberger T (2009) GABAergic interneurons targeting dendrites of pyramidal cells in the CA1 area of the hippocampus. Eur $\mathrm{J}$ Neurosci 30:947-957.

Klein KM, Pendziwiat M, Eilam A, Gilad R, Blatt I, Rosenow F, Kanaan M, Helbig I, Afawi Z; Israeli-Palestinian Epilepsy Family Consortium (2017) The phenotypic spectrum of ARHGEF9 includes intellectual disability, focal epilepsy and febrile seizures. J Neurol 264:1421-1425.

Kneussel M, Brandstätter JH, Laube B, Stahl S, Müller U, Betz H (1999) Loss of postsynaptic GABA(A) receptor clustering in gephyrin-deficient mice. J Neurosci 19:9289-9297.

Kohl C, Riccio O, Grosse J, Zanoletti O, Fournier C, Schmidt MV, Sandi C (2013) Hippocampal neuroligin-2 overexpression leads to reduced aggression and inhibited novelty reactivity in rats. PLoS One 8:e56871.

Körber C, Richter A, Kaiser M, Schlicksupp A, Mükusch S, Kuner T, Kirsch J, Kuhse J (2012) Effects of distinct collybistin isoforms on 
the formation of GABAergic synapses in hippocampal neurons. Mol Cell Neurosci 50:250-259.

Lesca G, Till M, Labalme A, Vallee D, Hugonenq C, Philip N, Edery P, Sanlaville D (2011) De novo Xq11.11 microdeletion including ARHGEF9 in a boy with mental retardation, epilepsy, macrosomia, and dysmorphic features. Am J Med Genet A 155A:1706-1711.

Li RW, Yu W, Christie S, Miralles CP, Bai J, Loturco JJ, De Blas AL (2005a) Disruption of postsynaptic GABA receptor clusters leads to decreased GABAergic innervation of pyramidal neurons. J Neurochem 95:756-770.

Li RW, Yu W, Christie S, Miralles CP, Bai J, Loturco JJ, De Blas AL (2005b) Disruption of postsynaptic GABA receptor clusters leads to decreased GABAergic innervation of pyramidal neurons. J Neurochem 95:756-770.

Li X, Serwanski DR, Miralles CP, Bahr BA, De Blas AL (2007) Two pools of Triton $X-100$-insoluble GABA $(A)$ receptors are present in the brain, one associated to lipid rafts and another one to the postsynaptic GABAergic complex. J Neurochem 102:1329-1345.

Li Y, Serwanski DR, Miralles CP, Fiondella CG, Loturco JJ, Rubio ME, De Blas AL (2010) Synaptic and nonsynaptic localization of protocadherin-gammaC5 in the rat brain. J Comp Neurol 518:3439-3463.

Li Y, Xiao H, Chiou TT, Jin H, Bonhomme B, Miralles CP, Pinal N, Ali R, Chen WV, Maniatis T, De Blas AL (2012) Molecular and functional interaction between protocadherin-gammaC5 and GABAA receptors. J Neurosci 32:11780-11797.

Lionel AC, Vaags AK, Sato D, Gazzellone MJ, Mitchell EB, Chen HY, Costain G, Walker S, Egger G, Thiruvahindrapuram B, Merico D, Prasad A, Anagnostou E, Fombonne E, Zwaigenbaum L, Roberts W, Szatmari P, Fernandez BA, Georgieva L, Brzustowicz LM, et al. (2013) Rare exonic deletions implicate the synaptic organizer Gephyrin (GPHN) in risk for autism, schizophrenia and seizures. Hum Mol Genet 22:2055-2066.

Liu Y, Yang XJ, Xia H, Tang CM, Yang K (2019) GABA releases from parvalbumin-expressing and unspecific GABAergic neurons onto CA1 pyramidal cells are differentially modulated by presynaptic GABA(B) receptors in mouse hippocampus. Biochem Biophys Res Commun 520:449-452.

Long P, May MM, James VM, Granno S, Johnson JP, Tarpey P, Stevenson RE, Harvey K, Schwartz CE, Harvey RJ (2015) Missense mutation R338W in ARHGEF9 in a family with X-linked intellectual disability with variable macrocephaly and macro-orchidism. Front Mol Neurosci 8:83.

Ludolphs M, Schneeberger D, Soykan T, Schäfer J, Papadopoulos T, Brose N, Schindelin H, Steinem C (2016) Specificity of collybistin-phosphoinositide interactions: impact of the individual protein domains. J Biol Chem 291:244-254.

Lüttjohann A, Fabene PF, van Luijtelaar G (2009) A revised Racine's scale for PTZ-induced seizures in rats. Physiol Behav 98:579-586.

Marco EJ, Abidi FE, Bristow J, Dean WB, Cotter P, Jeremy RJ, Schwartz CE, Sherr EH (2008) ARHGEF9 disruption in a female patient is associated with $\mathrm{X}$ linked mental retardation and sensory hyperarousal. J Med Genet 45:100-105.

Marsicano G, Lutz B (1999) Expression of the cannabinoid receptor CB1 in distinct neuronal subpopulations in the adult mouse forebrain. Eur J Neurosci 11:4213-4225.

Mayer S, Kumar R, Jaiswal M, Soykan T, Ahmadian MR, Brose N, Betz H, Rhee JS, Papadopoulos T (2013) Collybistin activation by GTP-TC10 enhances postsynaptic gephyrin clustering and hippocampal GABAergic neurotransmission. Proc Natl Acad Sci USA 110:20795-20800.

Megías M, Emri Z, Freund TF, Gulyás Al (2001) Total number and distribution of inhibitory and excitatory synapses on hippocampal CA1 pyramidal cells. Neuroscience 102:527-540.

Mikhailova MA, Bass CE, Grinevich VP, Chappell AM, Deal AL, Bonin KD, Weiner JL, Gainetdinov RR, Budygin EA (2016) Optogenetically-induced tonic dopamine release from VTA-nucleus accumbens projections inhibits reward consummatory behaviors. Neuroscience 333:54-64.
Miles R, Tóth K, Gulyás Al, Hájos N, Freund TF (1996) Differences between somatic and dendritic inhibition in the hippocampus. Neuron 16:815-823.

Miralles CP, Taylor MJ, Bear J Jr, Fekete CD, George S, Li Y, Bonhomme B, Chiou TT, De Blas AL (2020) Expression of protocadherin- $\gamma \mathrm{C} 4$ protein in the rat brain. J Comp Neurol 528:840864.

Mortensen M, Patel B, Smart T (2012) GABA potency at GABAA receptors found in synaptic and extrasynaptic zones. Front Cell Neurosci 6:1.

Mukherjee J, Kretschmannova K, Gouzer G, Maric HM, Ramsden S, Tretter V, Harvey K, Davies PA, Triller A, Schindelin H, Moss SJ (2011) The residence time of GABA(A)Rs at inhibitory synapses is determined by direct binding of the receptor $\alpha 1$ subunit to gephyrin. J Neurosci 31:14677-14687.

Nathanson AJ, Zhang Y, Smalley JL, Ollerhead TA, Rodriguez Santos MA, Andrews PM, Wobst HJ, Moore YE, Brandon NJ, Hines RM, Davies PA, Moss SJ (2019) Identification of a core amino acid motif within the $\alpha$ subunit of $\mathrm{GABA}_{\mathrm{A}} \mathrm{Rs}$ that promotes inhibitory synaptogenesis and resilience to seizures. Cell Rep 28:670-681.e8.

Nusser Z, Sieghart W, Benke D, Fritschy JM, Somogyi P (1996) Differential synaptic localization of two major gamma-aminobutyric acid type A receptor alpha subunits on hippocampal pyramidal cells. Proc Natl Acad Sci USA 93:11939-11944.

Nyíri G, Freund TF, Somogyi P (2001) Input-dependent synaptic targeting of alpha(2)-subunit-containing GABA(A) receptors in synapses of hippocampal pyramidal cells of the rat. Eur $\mathrm{J}$ Neurosci 13:428-442.

Papadopoulos T, Korte M, Eulenburg V, Kubota H, Retiounskaia M, Harvey RJ, Harvey K, O'Sullivan GA, Laube B, Hülsmann S, Geiger JR, Betz H (2007) Impaired GABAergic transmission and altered hippocampal synaptic plasticity in collybistin-deficient mice. EMBO J 26:3888-3899.

Papadopoulos T, Eulenburg V, Reddy-Alla S, Mansuy IM, Li Y, Betz $\mathrm{H}$ (2008) Collybistin is required for both the formation and maintenance of GABAergic postsynapses in the hippocampus. Mol Cell Neurosci 39:161-169.

Papadopoulos T, Schemm R, Grubmüller H, Brose N (2015) Lipid binding defects and perturbed synaptogenic activity of a Collybistin $\mathrm{R} 290 \mathrm{H}$ mutant that causes epilepsy and intellectual disability. J Biol Chem 290:8256-8270.

Papadopoulos T, Rhee HJ, Subramanian D, Paraskevopoulou F, Mueller R, Schultz C, Brose N, Rhee JS, Betz H (2017) Endosomal phosphatidylinositol 3-phosphate promotes gephyrin clustering and GABAergic neurotransmission at inhibitory postsynapses. $J$ Biol Chem 292:1160-1177.

Papp A, Fehér O, Erdélyi L (1987) The ionic mechanism of the pentylenetetrazol convulsions. Acta Biol Hung 38:349-361.

Paul A, Crow M, Raudales R, He M, Gillis J, Huang ZJ (2017) Transcriptional architecture of synaptic communication delineates GABAergic neuron identity. Cell 171:522-539.e20.

Pelkey KA, Chittajallu R, Craig MT, Tricoire L, Wester JC, McBain CJ (2017) Hippocampal GABAergic inhibitory interneurons. Physiol Rev 97:1619-1747.

Poulopoulos A, Aramuni G, Meyer G, Soykan T, Hoon M, Papadopoulos T, Zhang M, Paarmann I, Fuchs C, Harvey K, Jedlicka P, Schwarzacher SW, Betz H, Harvey RJ, Brose N, Zhang W, Varoqueaux F (2009) Neuroligin 2 drives postsynaptic assembly at perisomatic inhibitory synapses through gephyrin and collybistin. Neuron 63:628-642.

Racine RJ (1972) Modification of seizure activity by electrical stimulation. II. Motor seizure. Electroencephalogr Clin Neurophysiol 32:281-294.

Reddy-Alla S, Schmitt B, Birkenfeld J, Eulenburg V, Dutertre S, Böhringer C, Götz M, Betz H, Papadopoulos T (2010) PH-domaindriven targeting of collybistin but not $\mathrm{Cdc} 42$ activation is required for synaptic gephyrin clustering. Eur J Neurosci 31:1173-1184. 
Saiepour L, Fuchs C, Patrizi A, Sassoè-Pognetto M, Harvey RJ, Harvey K (2010) Complex role of collybistin and gephyrin in GABAA receptor clustering. J Biol Chem 285:29623-29631.

Salesse C, Mueller CL, Chamberland S, Topolnik L (2011) Age-dependent remodelling of inhibitory synapses onto hippocampal CA1 oriens-lacunosum moleculare interneurons. J Physiol 589:4885-4901.

Schweizer C, Balsiger S, Bluethmann H, Mansuy IM, Fritschy JM, Mohler H, Luscher B (2003) The gamma 2 subunit of GABA(A) receptors is required for maintenance of receptors at mature synapses. Mol Cell Neurosci 24:442-450.

Serwanski DR, Miralles CP, Christie SB, Mehta AK, Li X, De Blas AL (2006) Synaptic and nonsynaptic localization of GABAA receptors containing the alpha5 subunit in the rat brain. J Comp Neurol 499:458-470.

Shimojima K, Sugawara M, Shichiji M, Mukaida S, Takayama R, Imai $\mathrm{K}$, Yamamoto T (2011) Loss-of-function mutation of collybistin is responsible for X-linked mental retardation associated with epilepsy. J Hum Genet 56:561-565.

Sik A, Penttonen M, Ylinen A, Buzsáki G (1995) Hippocampal CA1 interneurons: an in vivo intracellular labeling study. J Neurosci 15:6651-6665.

Singh P, Singh D, Goel RK (2016) Protective effect on phenytoin-induced cognition deficit in pentylenetetrazol kindled mice: a repertoire of Glycyrrhiza glabra flavonoid antioxidants. Pharm Biol 54:1209-1218.

Sloviter RS, Ali-Akbarian L, Elliott RC, Bowery BJ, Bowery NG (1999) Localization of GABA(B) (R1) receptors in the rat hippocampus by immunocytochemistry and high resolution autoradiography, with specific reference to its localization in identified hippocampal interneuron subpopulations. Neuropharmacology 38:1707-1721.

Soykan T, Schneeberger D, Tria G, Buechner C, Bader N, Svergun D, Tessmer I, Poulopoulos A, Papadopoulos T, Varoqueaux F, Schindelin H, Brose N (2014) A conformational switch in collybistin determines the differentiation of inhibitory postsynapses. EMBO $\mathrm{J}$ 33:2113-2133.

Stauffer WR, Lak A, Yang A, Borel M, Paulsen O, Boyden ES, Schultz W (2016) Dopamine neuron-specific optogenetic stimulation in rhesus macaques. Cell 166:1564-1571.e6.

Tretter V, Jacob TC, Mukherjee J, Fritschy JM, Pangalos MN, Moss SJ (2008) The clustering of GABA(A) receptor subtypes at inhibitory synapses is facilitated via the direct binding of receptor alpha 2 subunits to gephyrin. J Neurosci 28:1356-1365.

Tretter V, Kerschner B, Milenkovic I, Ramsden SL, Ramerstorfer J, Saiepour L, Maric HM, Moss SJ, Schindelin H, Harvey RJ,
Sieghart W, Harvey K (2011) Molecular basis of the gamma-aminobutyric acid $A$ receptor alpha3 subunit interaction with the clustering protein gephyrin. J Biol Chem 286:37702-37711.

Tyagarajan SK, Ghosh H, Harvey K, Fritschy J-M (2011) Collybistin splice variants differentially interact with gephyrin and Cdc42 to regulate gephyrin clustering at GABAergic synapses. J Cell Sci 124:2786-2796.

Van Zandt M, Weiss E, Almyasheva A, Lipior S, Maisel S, Naegele JR (2019) Adeno-associated viral overexpression of neuroligin 2 in the mouse hippocampus enhances GABAergic synapses and impairs hippocampal-dependent behaviors. Behav Brain Res 362:7-20.

Varoqueaux F, Jamain S, Brose N (2004) Neuroligin 2 is exclusively localized to inhibitory synapses. Eur J Cell Biol 83:449-456.

Wang JY, Zhou P, Wang J, Tang B, Su T, Liu XR, Li BM, Meng H, Shi YW, Yi YH, He N, Liao WP (2018) ARHGEF9 mutations in epileptic encephalopathy/intellectual disability: toward understanding the mechanism underlying phenotypic variation. Neurogenetics 19:9-16.

Wisden W, Laurie DJ, Monyer H, Seeburg PH (1992) The distribution of 13 GABAA receptor subunit mRNAs in the rat brain. I. Telencephalon, diencephalon, mesencephalon. J Neurosci 12:1040-1062.

Yamasaki T, Hoyos-Ramirez E, Martenson JS, Morimoto-Tomita M, Tomita S (2017) GARLH family proteins stabilize GABA(A) receptors at synapses. Neuron 93:1138-1152.e6.

Yao R, Zhang Y, Liu J, Wang J, Xu Y, Li N, Wang J, Yu T (2020) Clinical and molecular characterization of three novel ARHGEF9 mutations in patients with developmental delay and epilepsy. $\mathrm{J}$ Mol Neurosci 70:908-915.

Yu W, Jiang M, Miralles CP, Li RW, Chen G, de Blas AL (2007) Gephyrin clustering is required for the stability of GABAergic synapses. Mol Cell Neurosci 36:484-500.

Yu W, Charych El, Serwanski DR, Li RW, Ali R, Bahr BA, De Blas AL (2008) Gephyrin interacts with the glutamate receptor interacting protein 1 isoforms at GABAergic synapses. J Neurochem 105:2300-2314.

Zalocusky KA, Ramakrishnan C, Lerner TN, Davidson TJ, Knutson B, Deisseroth K (2016) Nucleus accumbens D2R cells signal prior outcomes and control risky decision-making. Nature 531:642646.

Zhu H, Pleil KE, Urban DJ, Moy SS, Kash TL, Roth BL (2014) Chemogenetic inactivation of ventral hippocampal glutamatergic neurons disrupts consolidation of contextual fear memory. Neuropsychopharmacology 39:1880-1892. 